\title{
UV Light Acclimation Capacity of Leaf Photosynthetic and Photochemical Behaviour in Near-isohydric and Anisohydric Grapevines in Hot and Dry Environments
}

\author{
A. Fernandes de Oliveira*, F. Rais, I. Dettori, M. Azzena, G. Nieddu \\ Department of Agriculture, University of Sassari, Viale Italia 39, 07100 Sassari, Italy
}

Submitted for publication: September 2018

Accepted for publication: March 2019

Keywords: UV radiation, heat stress, growth, net assimilation, PSII photoinhibition and recovery, anthocyanin, flavonols

\begin{abstract}
The photosynthetic and photochemical adaptation of grapevine leaves to high UV radiation, under hot and dry summer conditions, was investigated in near-isohydric Cannonau (syn. Grenache) and nearanisohydric Bovale grande (syn. Carignan). From pea-size stage until harvest, vines with mild to moderate water deficit were subjected to UV-blocking treatment (-UV) and compared to a control exposed to sunlight (C). Canopy light and thermal microclimate, growth and density, maximum leaf gas exchange, primary photochemistry (PSII) and phenols were monitored. Average increments in canopy temperature under - UV tunnels during day-time and night-time were $3.3^{\circ} \mathrm{C}$ and $0.8^{\circ} \mathrm{C}$ in Bovale grande and $2.6^{\circ} \mathrm{C}$ and $1.1^{\circ} \mathrm{C}$ in Cannonau. Cultivars reached similar leaf area, intrinsic water-use efficiency and stem water potential under $\mathrm{C}$ and -UV. Cannonau showed lower stomatal conductance, maximum net assimilation and transpiration rates, but also faster recovery of PSII under heat and moderate water stress. UV radiation induced a stronger and longer impact on leaf assimilation, but the duration of elevated temperatures under -UV induced higher photoinhibition and lower photochemical efficiency. A similar degree of correlation between leaf temperature and gas exchange was found among cultivars and treatments. In Cannonau, leaf anthocyanin decreased due to heat-induced long-lasting PSII photoinactivation under C. Conversely, Bovale grande showed higher phenolic content stability, thus higher photoprotection and recovery of PSII functional units. Agronomical practices affecting leaf phenolic accumulation influence canopy acclimation to heat and high sunlight. Vineyard management must avoid excessive canopy sun exposure and duration of elevated temperatures to favour high assimilation, while reducing photoinactivation and heat damage.
\end{abstract}

\section{INTRODUCTION}

In Mediterranean climate regions, plants are naturally exposed to elevated solar irradiance during their life cycle and, in many grapevine-growing areas, the frequency of extreme events, such as heat waves, has increased in the last decades. In such environments, high temperatures and elevated ultraviolet (UV) and photosynthetically active radiation (PAR) are frequently combined with drought (EEA, 2009). The latest global warming report predicts an average increase in ambient temperature of at least $1.5^{\circ} \mathrm{C}$ for the low and $2.6^{\circ} \mathrm{C}$ to $4.8^{\circ} \mathrm{C}$ for the high greenhouse gas emission scenarios by the end of the $21^{\text {st }}$ century (IPCC, 2018). Although recent projections suggest an ozone recovery by 2100 (Bais et al., 2015), recent studies have indicated that the decreasing trend in cloud cover over the Mediterranean Basin observed since 1970 will continue during the $21^{\text {st }}$ century, together with decreased precipitation (SanchezLorenzo et al., 2017) and increased surface downward solar radiation (Wild et al., 2015). UV radiation (280 to $400 \mathrm{~nm}$ ) reaching the Earth's surface is effective in regulating several physiological processes and metabolic pathways of plant development (Morales et al., 2013). The absorption of high UV levels, especially UV-B (280 to $315 \mathrm{~nm}$ ), can damage biological systems more than the simple heat or sunburn effect of solar radiation by degrading cellular DNA, and reducing plant photosynthesis, chloroplast thylakoid integrity and biomass production (Caldwell et al., 2003; Zlatev et al., 2012).

The biological impacts of UV-B radiation are effective even at low radiation intensities, leading to increased reactive oxygen species production and oxidative stress. Plant sensitivity to UV radiation seems to vary considerably among species and varieties. Some crops show high sensitivity to current natural UV-B levels, while others express great tolerance to enhanced doses (Teramura \&

\footnotetext{
*Corresponding author: E-mail address: acortez@uniss.it

Acknowledgements: The authors thank Dr Mario Santona, for technical support on vineyard management, and Mr Vincenzo Pani, Ms Mariella Leri and Mr Giuseppe Ginesu, for experimental tunnel installation and help with the vineyard management practices. In addition, the authors thank GMR Strumenti, Florence, Italy, for technical support
} 
Sullivan, 1991). For these reasons, and due to the great diversity of physiological and biochemical characteristics among varieties (Zarrouk et al., 2016), as well as the high plasticity and adaptive capacity found under different growing conditions (Lovisolo et al., 2016; Palliotti \& Poni, 2016), it is worthwhile to investigate grapevine responses to multiple environmental stresses influencing crop performances under natural conditions.

Several morphogenic mechanisms allow plants to cope with high temperature and sunlight levels during the different phenological stages (Cramer, 2010; Potters et al., 2006) in order to reduce negative impacts on growth and production. Among the plant mechanisms to tolerate abiotic constrains, a decrease in leaf gas exchange can be observed before a reduction in vegetative growth. In effect, photosynthesis is highly sensitive to heat and light stresses, and can be reduced either by the inhibition of photosystem II (PSII) activity and/ or by Rubisco inactivation during the primary carbon fixation steps of the Calvin cycle (Wahid et al., 2007; Luo et al., 2011; Feller, 2016). The inhibition of PSII activity leads to a reduction of chlorophyll fluorescence yield of PSII, which means that in vivo measurements of the rapid fluorescence kinetic curve (OJIP test) after leaf dark-adaptation (Strasser et al., 2004), together with leaf gas-exchange monitoring, may allow for a better understanding of the photoinhibition processes, as well as for evaluating abiotic stress tolerance, acclimation to high radiation stress, and the recovery capacity of different species and varieties (Luo et al., 2011; Xu et al., 2014). Reductions in grape net leaf $\mathrm{CO}_{2}$ assimilation by UV-B radiation occur in environments with naturally high sunlight, despite a rapid recovery of photochemical activity from UV photoinhibition induced by UV-screening phenolic substances (Kolb et al., 2001).

As in other important crops, varietal differences in grape physiological behaviour to avoid sunlight and high atmospheric water demand or drought-induced damage in leaves have been revealed in recent decades (Cramer, 2010; Rogiers et al., 2009; Sade et al., 2012). Grapevine varieties are considered drought-tolerant plants (Chaves et al., 2010) and are able to develop different strategies to respond to environmental constraints (Poni et al., 2018). The stomatal control over transpiration is particularly sensitive to abiotic stresses (Düring, 1998; Soar, 2006; Fernandes de Oliveira \& Nieddu, 2016b). Due to the combination of varietal differences in hydraulic properties and cellwall elasticity with hormonal signals, leaf gas exchange performance may vary greatly among cultivars, depending upon the growing conditions of the site (Hugalde \& Vila, 2018; Lovisolo et al., 2016). Nevertheless, the differences in stomatal regulation under drought conditions among the varieties studied to date make it possible to classify them as near-isohydric (pessimistic) or near-anisohydric (optimistic) (Schultz, 2003; Dal Santo et al., 2016; Zarrouk et al., 2016). Optimistic performance has been reported in Carignan under Mediterranean climate conditions, in comparison with the pessimistic response of varieties from the Grenache family (Chaves et al., 2010; Lovisolo et al., 2010; Keller, 2016; Fernandes de Oliveira \& Nieddu 2016b).

Overall, under high evaporative demand and conditions of water scarcity, near-isohydric varieties show tight stomatal control in order to maintain a constant leaf water potential (Schultz, 2003; Chaves et al., 2010). In near-anisohydric varieties, in contrast, the water potential drops faster until the leaf reaches the turgor-loss point and stomatal closure. Until this point, the leaves present higher stomatal conductance and thus higher $\mathrm{CO}_{2}$ assimilation (Lovisolo, 2010), but tend to show lower photosynthetic efficiency and photorespiration rate. Furthermore, although being less water-balance conservative, some near-anisohydric varieties may recover rapidly after drought due to higher resistance to cavitation under severe stress conditions, and hence may display higher photosynthetic productivity under mild to moderate water stress (Alsina et al., 2007; Lovisolo et al., 2010; Sade et al., 2012). Many varieties have shown photosynthetic and metabolic tolerance and high acclimation capacity to high insolation and temperature conditions (Young et al., 2016; Castagna et al., 2017). However, decreases in the intensity of leaf gas exchange and distinct behaviours among varieties have been reported in response to UV light, heat and drought conditions (Schultz, 2003; Alsina et al., 2007; Berli et al., 2010), and reductions in net assimilation and water losses during long stress periods are frequently combined with alterations in pigment balance, namely in UV-absorbing pigments (Kolb et al., 2001; Martínez-Lüscher et al., 2013; Del-Castillo-Alonso et al., 2016). By decreasing light absorption, this adjustment mechanism allows plants to protect the photosynthetic apparatus against reactive oxygen species, and thus to tolerate high irradiation levels, avoiding photoinhibition and photooxidation (Liakopoulos et al., 2007, Martínez-Lüscher et al., 2013).

Recent studies have suggested that changes in the photoinhibition dynamics and photoprotection capacity may also depend upon the plant's ability to rapidly synthesise phenolic compounds (Barnes et al., 2015). Besides, diurnal and seasonal variations in the accumulation of phenolics may be linked to changes in environmental irradiance levels (Šebela et al., 2017). We hypothesise that varietal differences in grapevine acclimation responses to UV radiation and heat stresses, so far as leaf photosynthesis and photochemistry performance are concerned, also depend on differences in leaf pigment-accumulation dynamics according to genetic differences in phenolic profiles (Xu et al., 2014; Fernandes de Oliveira et al., 2015). To investigate these relationships, two grapevine varieties that are widespread in Mediterranean viticultural areas (Anderson \& Aryal, 2013) were chosen for their different leaf gas exchange performance under water stress and high temperatures (Fernandes de Oliveira \& Nieddu, 2016b). During vegetative growth, the effects of UV radiation on grape leaf gas exchange, primary photochemistry and the non-invasive rapid evaluation of leaf pigment balance (Goulas et al., 2004) were analysed to detect alterations in assimilation capacity, photoinhibition and recovery capacity, and to investigate correlations with the accumulation of leaf pigment photoprotection mechanisms.

\section{MATERIALS AND METHODS}

\section{Plant material and experimental site}

The study was carried out in Oristano, Sardinia, Italy, on the red grape variety collection vineyard of the University of Sassari $\left(39^{\circ} 54^{\prime} 12^{\prime \prime} \mathrm{N}, 8^{\circ} 37^{\prime} 19^{\prime \prime} \mathrm{E}\right)$. The climate of the study 
area is classified as Mediterranean Pluviseasonal-Oceanic, with upper thermo-Mediterranean, lower dry, euoceanic weak horizons, according to the worldwide bioclimatic classification system (Canu et al., 2015). The altitude of the experimental farm is about $13 \mathrm{~m}$ above sea level, and the coastal plain that characterises the Oristano Gulf area gives rise to limited climate variability. Annual precipitation is about $540 \mathrm{~mm}$. The mean, maximum and minimum temperatures are $16.7^{\circ} \mathrm{C}, 21.3^{\circ} \mathrm{C}$ and $12.1^{\circ} \mathrm{C}$ respectively (Fick \& Hijmans, 2017). Mean, maximum and minimum daily solar exposure is about $15.7 \mathrm{MJ} / \mathrm{m}^{2}, 26.1 \mathrm{MJ} / \mathrm{m}^{2}$ (in July) and $6.8 \mathrm{MJ} / \mathrm{m}^{2}$ (in January) respectively.

The study was conducted on ten-year-old Bovale grande (syn. Carignan) and Cannonau (syn. Grenache) vines grafted onto 779 P rootstock and spaced $2.5 \mathrm{~m} \mathrm{x} 1.0 \mathrm{~m}$, spur-pruned to a unilateral cordon, of $1 \mathrm{~m}$ height and a maximum leaf wall height of $1.2 \mathrm{~m}$. The vineyard has a north-south row orientation and a single drip-line irrigation system $(4 \mathrm{~L} / \mathrm{h})$. In the collection field, grapevine varieties are arranged in three randomised blocks of 20 plants per variety. In each block, the two varieties studied are planted in two contiguous rows. During the 2016 season, two treatments were compared from pea size until harvest: 1) the UV-blocking treatment (-UV), in which the entire canopy of 10 plants of each variety per block was covered with an ultraviolet radiation-blocking filter - polycarbonate panels (Suntuf Plus Clear Embossed, Omega 76/16 profile and 0.8 thickness, Palram Europe Ltd., UK) - with elevated, visible solar radiation transmission ( $\geq 80 \%$ ); 2) the control (C), in which ten consecutive vines of each variety were kept directly exposed to ambient solar radiation. The UV-screening panels were mounted in a tunnel structure of $2.5 \mathrm{~m}$ in height, $5 \mathrm{~m}$ in width and 12 $\mathrm{m}$ in length. The north and south sides of the tunnel were left open, while the east and west sides of the vines were completely covered, leaving only $20 \mathrm{~cm}$ above the soil surface uncovered to promote natural ventilation. Inside the tunnels, the air temperature increased by about $2^{\circ} \mathrm{C}$ compared to the outside air temperature inside vine canopy, and reached on average maximum temperatures $5^{\circ} \mathrm{C}$ higher. Plants were deficit irrigated from pea size until the beginning of ripening, and weekly watering supplies were defined based on stem water potential, imposing a $-0.8 \mathrm{MPa}$ lower threshold in order to maintain a mild to moderate water deficit conditions (Myburgh, 2011). The total re-watering amount during the season was $130 \mathrm{~mm}$.

\section{Weather and microclimate data collection}

In order to describe the weather conditions during the trial, meteorological data were collected from the closest weather station (about $20 \mathrm{~km}$ from the study site) for which a longterm (30-year) series of data was available (Capo Frasca, $\left.39^{\circ} 44^{\prime} 23.59^{\prime \prime} \mathrm{N}, 8^{\circ} 27^{\prime} 34.15^{\prime \prime} \mathrm{E}\right)$.

Canopy thermo-hygrometric conditions were monitored continuously using small dataloggers (WatchDog A-Series Loggers, Spectrum Technologies Inc., UK) inside a radiation shield. Single light sensors of global solar radiation $(\mathrm{Rg})$, PAR, Red:Far red, UV-A and UV-B intensity, simultaneously coupled to a portable datalogger (Skye Instruments, Llandrindod Wells, Wales), were used to measure the incident radiation at the vineyard site, as well as the radiation transmission inside the tunnels. Light microclimate throughout the canopy layers, in PAR wavelengths (400 to $700 \mathrm{~nm}$ ), was monitored at the fruit zone and in an upper canopy layer (60 $\mathrm{cm}$ from the shoot base), as indicated in Fernandes de Oliveira and Nieddu (2016b), using a ceptometer connected to a total and diffuse PAR sunshine sensor (Sunscan SS1 and BF3; Delta T Devices, UK).

\section{Vegetative growth and canopy density}

Grape vegetative growth was evaluated during berry growth and ripening stages based on leaf area (LA) estimation models (Lopes \& Pinto, 2005) previously calibrated for Cannonau and Carignano. Shoot length, and the LA of the main and lateral shoot and vine, were determined in 12 shoot replicates per variety and treatment. In order to estimate grape leaf area development, the empirical models take into account a few variables that correlate well with the LA of the main and lateral shoot: number of primary and lateral leaves per shoot, and area of the largest and the smallest primary and lateral leaves, which allow for a good estimation of the mean leaf area. Single leaf area was estimated based on the length of the two lateral main veins. Canopy density was analysed using point quadrat analysis (Smart \& Robinson, 1991). Average leaf layer number (LLN) and the percentage of internal leaves (PIL) were determined taking into consideration the measurements taken during ripening at six height layers from the vegetative wall base (at 0,20 , $40,60,80$ and $100 \mathrm{~cm}$ from the shoot base) and replicated horizontally along $1 \mathrm{~m}$ of vine row at intervals of $20 \mathrm{~cm}$.

\section{Plant physiological status}

Plant water status was evaluated using midday stem water potential, $\Psi_{\text {Stem }}$, with a pump-up pressure chamber (PMS Instruments, USA). Weekly measurements were taken at solar midday (13:00) in intact adult leaves, covered with aluminium foil-coated plastic bags one hour prior to the measurement to allow for the equilibration of the leaf with the stem water status. Leaf gas exchange and direct chlorophyll fluorescence of PSII were monitored at midmorning (from 10.00 to $11.00 \mathrm{~h}$ ) on days with clear skies. This was done in vivo on well-exposed adult leaves chosen from the base and the apical parts of the main shoot (leaf position 4 to 6 and 10 to 12 respectively), at three phenological stages (cluster closure, véraison and ripening). Net assimilation ( $\mathrm{Pn}, \mu \mathrm{mol} / \mathrm{m}^{2} \mathrm{~s} \mathrm{CO}_{2}$ ), stomatal conductance $\left(\mathrm{g}_{\mathrm{s}}, \mathrm{mmol} / \mathrm{m}^{2} \mathrm{~s}\right)$ and transpiration $\left(\mathrm{T}, \mathrm{mmol} / \mathrm{m}^{2} \mathrm{~s} \mathrm{H}_{2} \mathrm{O}\right)$ rates and leaf temperature $\left(\mathrm{T}_{\text {leaf }}{ }^{\circ} \mathrm{C}\right)$ data were collected at ambient reference $\mathrm{CO}_{2}$ concentration $(370 \mu \mathrm{mol} / \mathrm{mol})$, and under the actual PAR, temperature and relative humidity conditions, using a portable infrared gas analyser (Ciras 2, PP systems, UK). Intrinsic water-use efficiency (WUEi, $\mu \mathrm{mol} / \mathrm{mol}$ ) was calculated as the ratio of net photosynthesis to stomatal conductance. After a 30-minute dark-adaptation period, the fluorescence transients (OJIP curve) were recorded using a HandyPEA fluorimeter (Hansatech Instruments Ltd., UK) during the application of actinic saturating red light $(650 \mathrm{~nm}$ wavelength) of $3000 \mu \mathrm{mol} / \mathrm{m}^{2} / \mathrm{s}$ single flash, with the signal gain at 1.0 and 30 seconds duration of each replicate. The rapid fluorescence kinetic from minimum $\left(\mathrm{F}_{\mathrm{o}}\right)$ to maximum 
$\left(\mathrm{F}_{\mathrm{m}}\right)$ fluorescence of the dark-adapted leaves was collected. The fluorescence signals were recorded at a $10 \mu \mathrm{s}$ time step, which allowed for determining the OJIP transient and calculating the main fluorescence variables and a range of derived variables for evaluating PSII activity during the photochemical and thermal phases of the fluorescence transient (Strasser, 2004). The maximum yield of primary photochemistry of PSII, $\varphi_{\mathrm{Po}}$, the maximum water-splitting efficiency, $\mathrm{F}_{\mathrm{v}} / \mathrm{F}_{\mathrm{o}}$, the quantum yield for electron transport, $\varphi_{\mathrm{Eo}}$, the quantum yield for energy dissipation, $\varphi_{\text {DIo }}$, and the density of the reaction centres, $\mathrm{RC}_{\mathrm{QA}}$, were determined using the equations reported in Table S1. Finally, another chlorophyll fluorescence-derived variable, $1 / \mathrm{F}_{\mathrm{o}}-1 / \mathrm{F}_{\mathrm{m}}$, suggested by Flexas et al. (2001) to be a more linear indicator of functional PSII units, was calculated.

\section{Leaf pigment estimation}

Leaf chlorophyll, anthocyanin, flavonol and nitrogen balance indexes were estimated in replicates of the basal and apical main shoot leaves during mid-morning on days with clear skies (at the cluster closure, beginning of and full véraison phenological stages), using an optical device, Dualex Scientific+ (FORCE-A, FR) (Cerovic et al., 2012). This portable device is equipped with a leaf clip sensor with a $6 \mathrm{~mm}$ diameter measuring surface, and allows for in situ and in vivo estimation of leaf epidermal phenolics (flavonols and anthocyanins), based on the chlorophyll fluorescencescreening method (Goulas et al., 2004) and leaf chlorophyll contents determined by differential transmittance (Cerovic et al., 2012). Four indexes were derived (Table S2): the chlorophyll index (CHL), the flavonol index (FLA), the anthocyanin index (ANT) and the nitrogen balance index (NBI). The latter is the ratio of leaf CHL to FLA epidermal content (Cartelat et al., 2005) and may give a good estimate of the leaf nitrogen content. In each leaf replicate, five measurements were taken at the adaxial and abaxial leaf sides, avoiding the main veins.

\section{Statistical analysis}

Analysis of variance (ANOVA) and the least significant difference (LSD) test were performed to compare means and to investigate significant differences at the $95 \%$ confidence level, using the software package SPSS statistics 20 (SPSS, Chicago, USA). Two-way ANOVA was performed in order to evaluate the main influences of cultivar, treatment and leaf level, as well as to detect interaction effects among factors. After scaling and normalising the data of each variable for which significant differences were detected, multi-factor analysis (MFA), followed by a Fisher's least-significant difference (LSD) test ( $\mathrm{p} \leq 0.05$ ), was carried out on leaf gas exchange, stem water potential, direct chlorophyll fluorescence variables, and leaf pigment and nitrogen balance indexes. The resulting loading and score plots highlighted common variations and made it possible to summarise the relationships among the variables, and to identify the main factors influencing the physiological patterns in the two cultivars and in the two treatments. Finally, orthogonal partial least squares discriminant analysis (OPLS-DA) was performed to discriminate treatment-cultivar groups as functions of the analysed variables and to identify which variables were the most distinctive in separating the four cultivar $\mathrm{x}$ treatment groups.

\section{RESULTS}

\section{Weather conditions}

The 2016 season was characterised by hot and dry conditions for most of the duration of the trial (Fig. S1). Monthly air temperatures were higher than the average values of the last 30 years in June, July and September, but remained under the average of the 30-year series in August. The environmental conditions of the growth season were aggravated by the limited precipitation during the entire spring/summer period in the study area, which also led to higher potential evapotranspiration throughout the season, especially in June and July. Rain events were practically absent in June and remained lower than the last 30-year average values in July and August.

\section{Light and thermal microclimatic conditions}

The daily pattern of Rg, PAR, UV-A and UV-B incident solar radiation at the experimental site, and the average values transmitted by the plastic filter, measured at $\mathrm{BBCH}$ stage 74 on a day with clear sky, are presented in Fig. 1. The $\mathrm{Rg}$ and PAR intensity at 09:00 averaged $1937 \mathrm{~W} / \mathrm{m}^{2}$ and $933 \mu \mathrm{mol} / \mathrm{m}^{2} \mathrm{~s}$ respectively, and midday maximum values were about $3750 \mathrm{~W} / \mathrm{m}^{2}$ and $1800 \mu \mathrm{mol} / \mathrm{m}^{2} \mathrm{~s}$ respectively. Under the UV-screening filter, incident $\mathrm{Rg}$ and PAR were reduced to $1540 \mathrm{~W} / \mathrm{m}^{2}$ and $742 \mu \mathrm{mol} / \mathrm{m}^{2}$ s respectively at 09:00, and similar values were recorded by the end of the afternoon. In the $-\mathrm{UV}$ treatment, mid-morning $\mathrm{Rg}$ and PAR intensity at the top of the canopy reached $2200 \mathrm{~W} / \mathrm{m}^{2}$ and $1050 \mu \mathrm{mol} / \mathrm{m}^{2}$ s. The UV filter blocked $99 \%$ of UV-B and $87 \%$ of UV-A solar radiation, while the Red:Far red varied close to the values of the environmental control treatment. No significant differences within varieties were observed in light transmission inside the canopy at this stage, and only slight differences were detected between -UV Bovale grande and $-\mathrm{UV}$ Cannonau plants during ripening $(\mathrm{BBCH}$ stage 85) (Fig. S2).

As far as the air temperature inside the canopy is concerned, the UV-screening filter induced an average increase of about $0.8^{\circ} \mathrm{C}$ and $1.1^{\circ} \mathrm{C}$ in Bovale grande and Cannonau respectively at night, while the daytime increases averaged $3.3^{\circ} \mathrm{C}$ and $2.6^{\circ} \mathrm{C}$ in the Bovale grande and Cannonau respectively (Fig. 2). The differences in canopy temperature were not significant among cultivars, while the higher temperatures recorded under the ultraviolet-blocking filter in the daytime were observed during the entire season of the trial (Fig. S3). Although the percentage duration of temperatures higher than $25^{\circ} \mathrm{C}$ showed no statistical differences among varieties and treatments, temperatures over $35^{\circ} \mathrm{C}$ were recorded inside the -UV canopies for $16 \%$ and $20 \%$ of the trial duration in Cannonau and Bovale grande respectively, compared to the low $2 \%$ duration in the Control (Fig. 3). The canopy temperature exceeded $40^{\circ} \mathrm{C}$ only in the $-\mathrm{UV}$ treatments, but this occurred for only $2 \%$ of the duration of the trial (ca. 25 hours overall). Nevertheless, on extremely hot days, the canopy temperature experienced the $40^{\circ} \mathrm{C}$ threshold for as many as two to five consecutive hours (Fig. S3). 
(a)
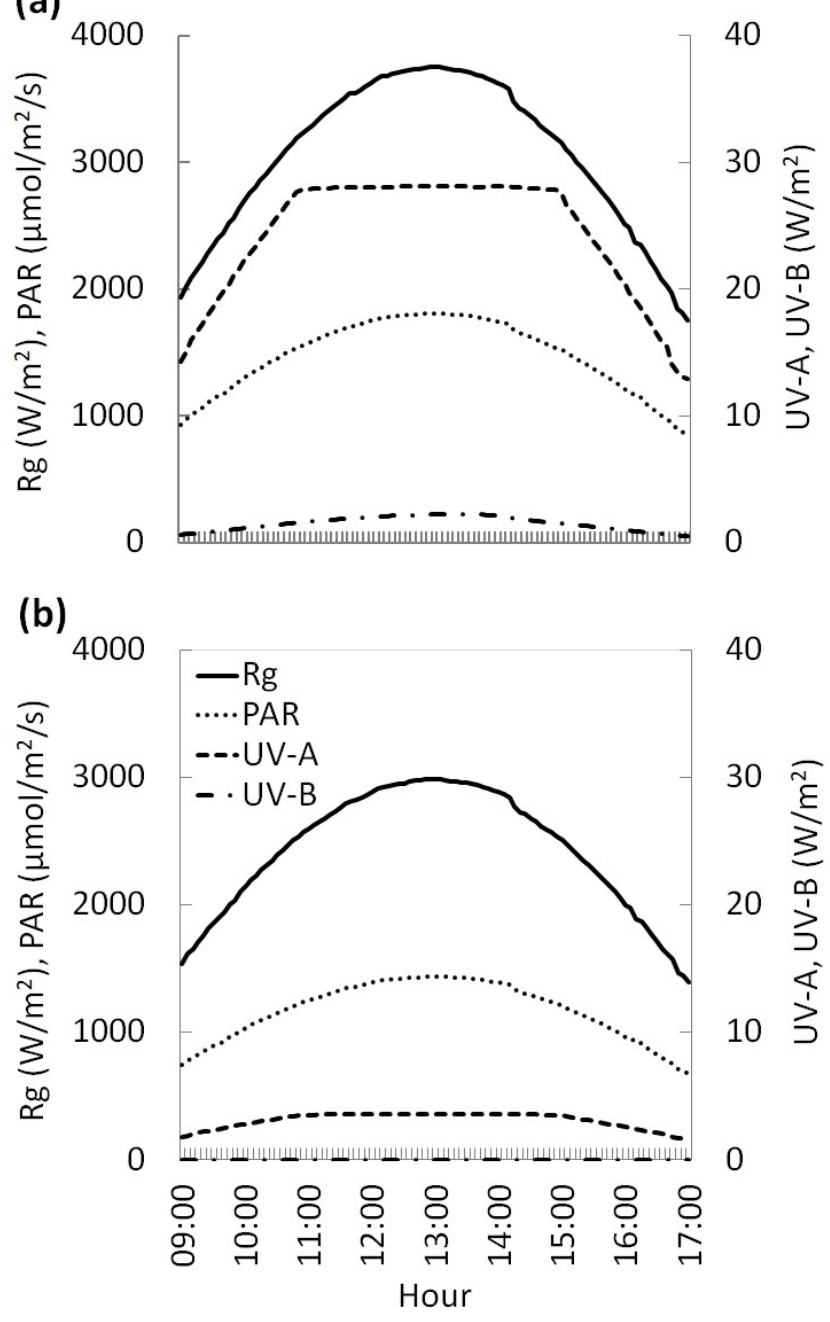

FIGURE 1

Sunlight intensity (a) at the top of the canopy outside (incident radiation) and (b) inside the UV-screening filter (film transmitted radiation). Global solar radiation $(\mathrm{Rg}, \mathrm{W} /$ $\mathrm{m}^{2}$ ), photosynthetically active radiation (PAR, $\mu \mathrm{mol} / \mathrm{m}^{2} \mathrm{~s}$ ), ultraviolet A (UV-A, W/m²) and ultraviolet B (UV-B, W/m²) radiation, from 9.00 until 17.00 hours at the beginning of the experiment, in a clear sky day (DOY 182).

\section{Vegetative growth}

Leaf area development was evaluated at flowering (stage 65 ), cluster closure (stage 75 ) and two weeks after véraison (stage 85) (Fig. 4a). The main single LA of Bovale grande was significantly greater than that of Cannonau, averaging about $200 \mathrm{~cm}^{2}$ at the maximum development stage (BBCH 75) against the $100 \mathrm{~cm}^{2}$ of Cannonau. Also, the lateral leaves were bigger in Bovale grande compared to Cannonau, and the highest average values were measured after véraison, averaging $64 \mathrm{~cm}^{2}$ and $43 \mathrm{~cm}^{2}$ respectively. No significant effect of the UV-screening treatment was observed in single LA, nor in the main and lateral LA per plant (Table S3). Varietal differences were detected in leaf area development, with Cannonau presenting much lower main LA compared to Bovale grande. During the three stages monitored (flowering,

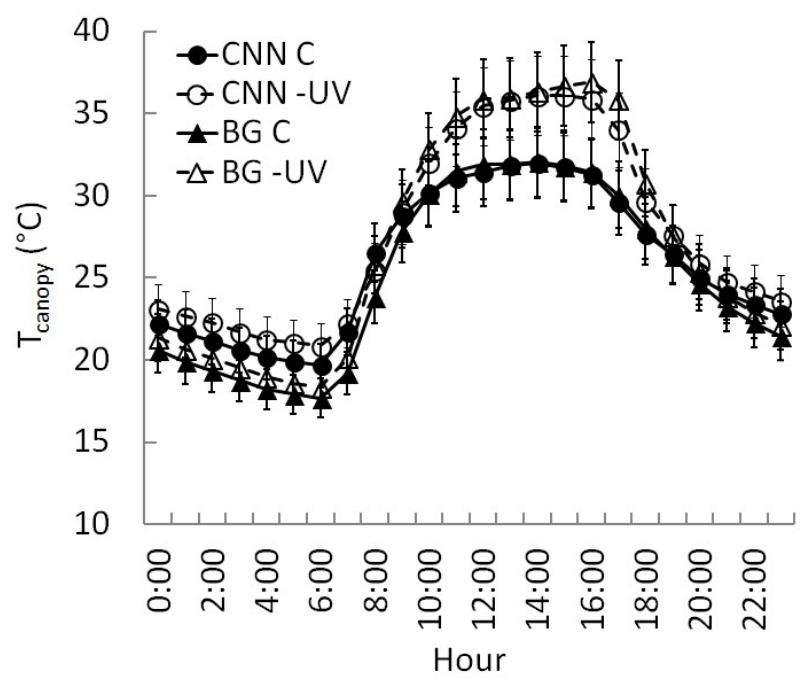

FIGURE 2

Average daily pattern of canopy temperature $\left(\mathrm{T}_{\text {canopy, }}{ }^{\circ} \mathrm{C}\right)$ of Bovale grande $(\mathrm{BG})$ and Cannonau $(\mathrm{CNN})$ plants outside (Control, C) and inside the UV-screening filter (-UV). Mean

$$
(n=3) \pm \text { SE. }
$$

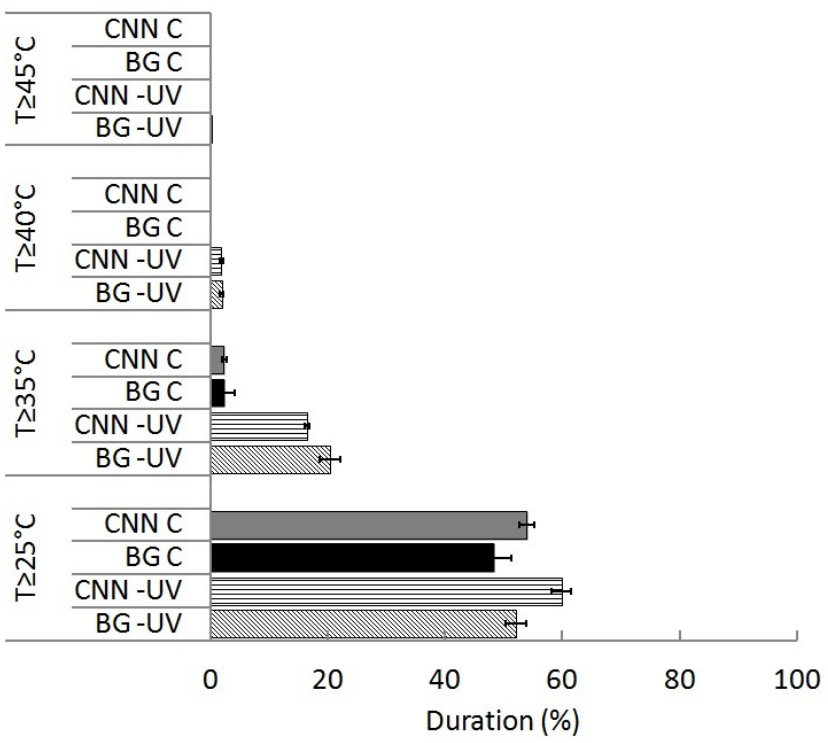

FIGURE 3

Percent duration of canopy temperature above 25, 35, 40 and $45^{\circ} \mathrm{C}$ thresholds, during the experimental season, in Bovale grande $(\mathrm{BG})$ and Cannonau $(\mathrm{CNN})$ plants outside (Control, C) and inside the UV-screening filter $(-U V)$. Mean $(n=3) \pm$ SE.

pea-sized berries and ripening), the main leaves represented about $70 \%, 46 \%$ and $40 \%$ of total LA in Cannonau, and $91 \%$, $86 \%$ and $75 \%$ in Bovale grande. The difference in main LA development was counterbalanced by a significantly higher production of lateral shoots in Cannonau plants (Fig. 4a), allowing the plants to keep a similar vegetative surface as the season proceeded. Only at the first measuring date did Bovale grande present a higher total LA compared to 

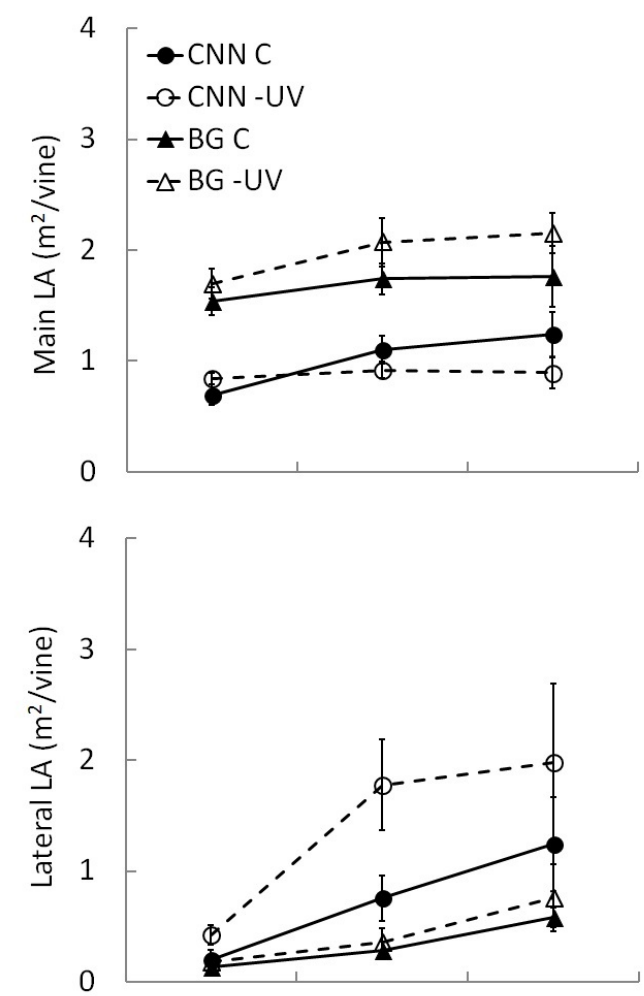

志

芆窝
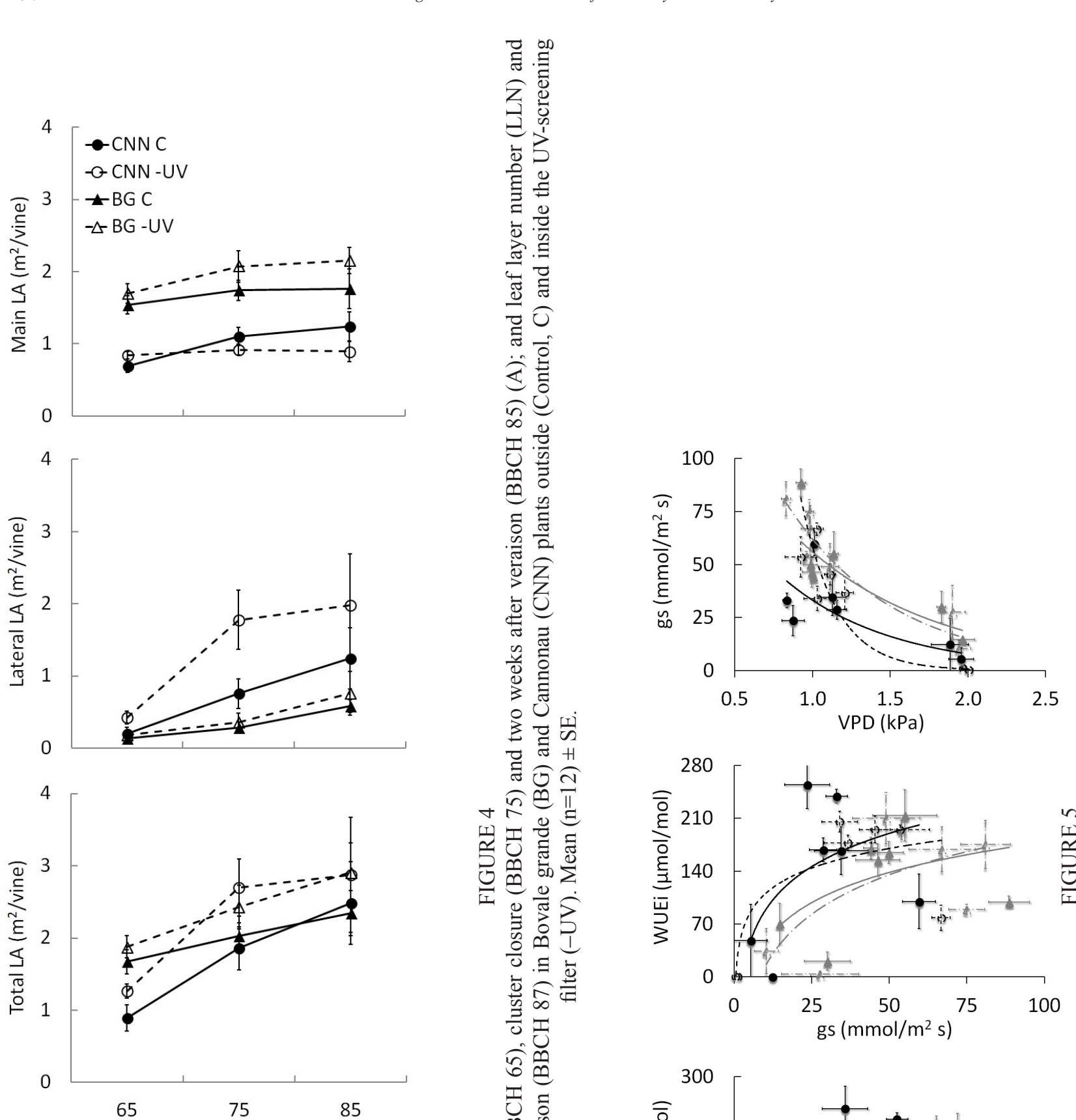

(a)
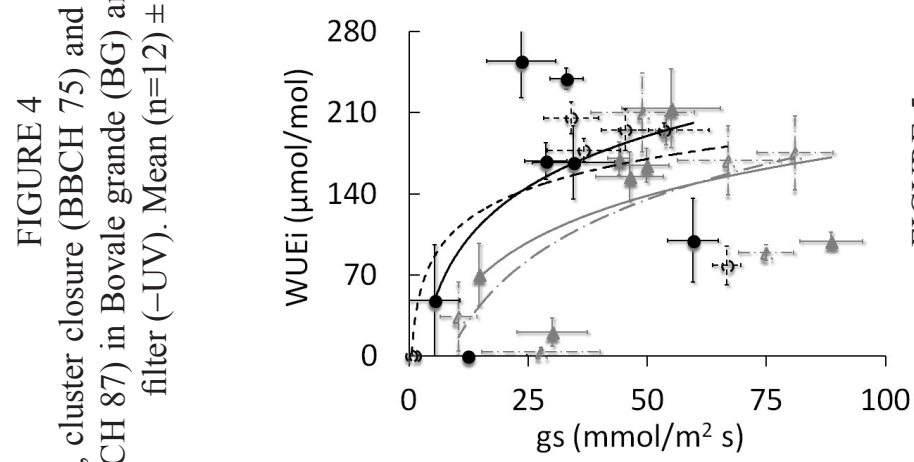

龸

됴요

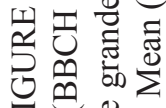

至完

至

它 $\cong$.

营

สิ

gs $\left(\mathrm{mmol} / \mathrm{m}^{2} \mathrm{~s}\right)$

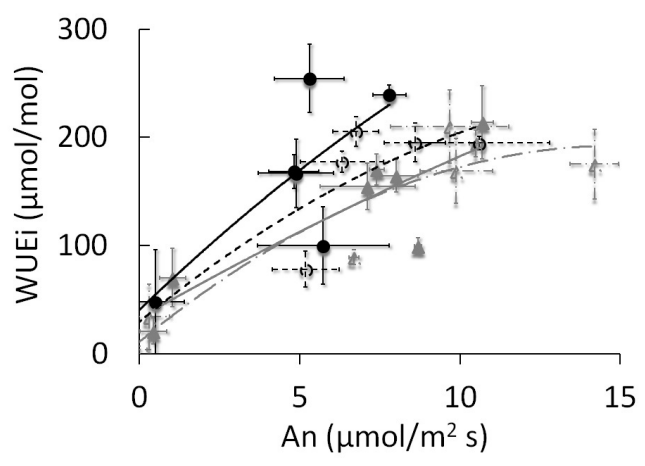

I

记

.

苛

ลิ

它

望

ฐี
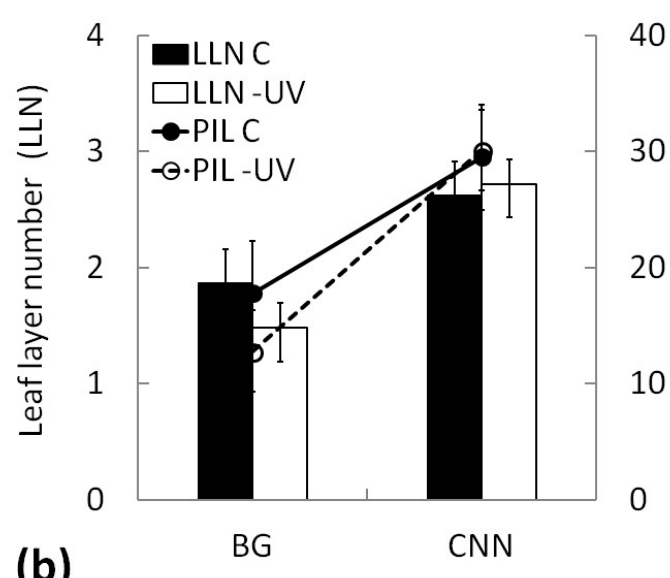

(b)

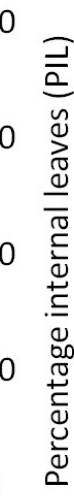

三

$\stackrel{\Xi}{\Xi}$

ฟี

\&

$\stackrel{\leftrightarrow}{\exists}$

है

䜦

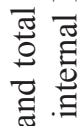

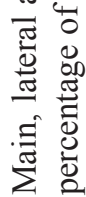


Cannonau. The latter presented slightly but not statistically higher total LA during ripening (stage 85), but also a higher canopy density, with average LLN and PIL values of $2.7 \%$ and $30 \%$ respectively, against the $1.7 \%$ and $15 \%$ of Bovale grande (Fig. 4b).

\section{Plant water status}

Plant water status ranged from mild to moderate water stress over the entire season of the trial (Table 1). Two re-watering supplies (of about $150 \mathrm{~m}^{3} / \mathrm{ha}$ each) were applied from fruit set to cluster closure. The lowest $\Psi_{\text {Stem }}$ values (ca. -1.2 MPa) were observed at cluster closure stage $(\mathrm{BBCH} 75)$ after two weeks of constant increments in maximum and minimum air temperature and a prolonged dry period (60 days without precipitation and only one day of effective rainfall, with $7.9 \mathrm{~mm}$ of total rainfall). As the atmospheric evaporative demand increased, a similar decrease in $\Psi_{\text {Stem }}$ was observed among varieties and treatments. Thereafter, irrigation was applied weekly $\left(210 \mathrm{~m}^{3} / \mathrm{ha}\right)$, allowing for the plants to recover to a mild water stress status (about $-0.95 \mathrm{MPa}$ and $-0.85 \mathrm{MPa}$ at stages 80 and 83 respectively). The irrigation volume was reduced by the end of véraison $\left(105 \mathrm{~m}^{3} / \mathrm{ha} /\right.$ week $)$, and the last irrigation supply was applied two weeks after véraison, totalling about $1300 \mathrm{~m}^{3} / \mathrm{ha}$ for the whole season.

\section{Leaf gas exchange and photosynthetic performance}

Leaf gas exchange rates were similar in the basal and apical main leaves until véraison (Table 1). Higher rates in young apical leaves were only observed by ripening stage 85 (with average values of $\mathrm{Pn}$, gs and $\mathrm{T}$ of about $7.5 \mu \mathrm{mol} / \mathrm{m}^{2} \mathrm{~s}, 39$ $\mathrm{mmol} / \mathrm{m}^{2} \mathrm{~s}$ and $1.7 \mathrm{mmol} / \mathrm{m}^{2} \mathrm{~s}$ in the basal leaves respectively, against $10.8 \mu \mathrm{mol} / \mathrm{m}^{2} \mathrm{~s}, 56 \mathrm{mmol} / \mathrm{m}^{2} \mathrm{~s}$ and $2.4 \mathrm{mmol} / \mathrm{m}^{2} \mathrm{~s}$ in the apical leaves). Nevertheless, at this stage the basal leaves were still able to reach maximum values of $\mathrm{Pn}, \mathrm{g}_{\mathrm{s}}$ and $\mathrm{T}$ similar to those of the previous measurements (Table 1). During the first weeks of the trial (stage 75), the treatments did not induce significant differences in mid-morning leaf gas exchange intensity (reaching average $\mathrm{Pn}$, gs and $\mathrm{T}$ values of $5.9 \mu \mathrm{mol} / \mathrm{m}^{2} \mathrm{~s}, 71 \mathrm{mmol} / \mathrm{m}^{2} \mathrm{~s}$ and $2.4 \mathrm{mmol} / \mathrm{m}^{2} \mathrm{~s}$ respectively in the $-\mathrm{UV}$ leaves and $7.2 \mu \mathrm{mol} / \mathrm{m}^{2} \mathrm{~s}, 74 \mathrm{mmol} / \mathrm{m}^{2} \mathrm{~s}$ and $1.8 \mathrm{mmol} / \mathrm{m}^{2} \mathrm{~s}$ in the control). However, highly significant differences in stomatal behaviour were observed among

\section{TABLE 1}

Effects of leaf level (basal and apical), cultivar (Bovale grande, BG, and Cannonau, CNN) and treatment (UV-screening, -UV, and Control exposed to direct solar radiation, C) on stem water potential $\left(\Psi_{\text {Stem }}\right)$, net photosynthesis $(\mathrm{Pn})$, stomatal conductance $\left(\mathrm{g}_{\mathrm{s}}\right)$, transpiration $(\mathrm{T})$ rates, intrinsic water-use efficiency (WUEi), leaf temperature $\left(\mathrm{T}_{\text {leaf }}\right)$, leaf-to-air vapour pressure deficit (VPD), and the chlorophyll (CHL), anthocyanin (ANT), flavonol (FLA) and nitrogen balance (NBI) indexes during the experimental season. Means in columns followed by different letters are significantly different, within main effects on the basis of LSD performed by two-way ANOVA (analysis of variance) at $p<0.05(\mathrm{n}=6)$.

\begin{tabular}{|c|c|c|c|c|c|c|c|c|c|c|c|c|c|}
\hline $\begin{array}{l}\mathrm{BBCH} \\
\text { stage }\end{array}$ & Main effect & & $\Psi_{\text {stem }}$ & Pn & $g_{s}$ & $\mathrm{~T}$ & WUEi & $\mathrm{T}_{\text {leaf }}$ & VPD & CHL & ANT & FLA & NBI \\
\hline \multirow{6}{*}{75} & \multirow[t]{2}{*}{ Leaf } & Basal & - & 6.6 & 72 & 2.1 & 92 & 29.5 & 0.99 & 29.8 & 0.20 & 3.43 & 8.78 \\
\hline & & Apical & - & - & - & - & - & - & - & - & - & - & - \\
\hline & \multirow[t]{2}{*}{$\mathrm{cv}$} & BG & $-0.88 b$ & 7.7 & $82 \mathrm{a}$ & 2.1 & 94 & $28.7 \mathrm{~b}$ & $0.95 \mathrm{~b}$ & 31.6 & $0.17 \mathrm{~b}$ & 3.37 & 9.44 \\
\hline & & $\mathrm{CNN}$ & $-0.73 a$ & 5.4 & $63 \mathrm{~b}$ & 2.1 & 89 & $30.3 \mathrm{a}$ & $1.02 \mathrm{a}$ & 27.9 & $0.23 \mathrm{a}$ & 3.48 & 8.11 \\
\hline & \multirow[t]{2}{*}{ Treatment } & $-U V$ & -0.77 & 5.9 & 71 & 2.4 & 74 & $28.5 \mathrm{~b}$ & 1.00 & 31.3 & 0.18 & 3.42 & 9.22 \\
\hline & & $\mathrm{C}$ & -0.85 & 7.2 & 74 & 1.8 & 100 & $30.5 \mathrm{a}$ & 0.97 & 28.2 & 0.22 & 3.44 & 8.33 \\
\hline \multirow[t]{9}{*}{$p$-value } & \multicolumn{2}{|l|}{$\mathrm{P}_{\text {(level) }}$} & - & - & - & - & - & - & - & - & - & - & - \\
\hline & \multicolumn{2}{|l|}{$P_{(\mathrm{cv})}$} & 0.019 & 0.095 & 0.003 & 0.977 & 0.806 & 0.012 & 0.047 & 0.174 & 0.011 & 0.512 & 0.184 \\
\hline & \multicolumn{2}{|l|}{$\mathrm{P}_{\text {(treatment) }}$} & 0.143 & 0.311 & 0.480 & 0.474 & 0.458 & 0.005 & 0.255 & 0.257 & 0.133 & 0.858 & 0.358 \\
\hline & \multicolumn{2}{|l|}{$\mathrm{P}_{\text {(level x cv) }}$} & - & - & - & - & - & - & - & - & - & - & - \\
\hline & \multicolumn{2}{|l|}{$\mathrm{P}_{\text {(level x treatment) }}$} & - & - & - & - & - & - & - & - & - & - & - \\
\hline & \multicolumn{2}{|l|}{$\mathrm{P}_{\text {(cv x treatment) }}$} & - & 0.359 & 0.048 & 0.688 & 0.779 & 0.375 & 0.490 & 0.479 & 0.106 & 0.855 & 0.507 \\
\hline & \multicolumn{2}{|c|}{$\mathrm{P}_{\text {(level x cv x treatment) }}$} & - & - & - & - & - & - & - & - & - & - & - \\
\hline & \multirow[t]{2}{*}{ Leaf } & Basal & - & -0.6 & 13 & 0.6 & 14 & 39.1 & 1.91 & 28.2 & 0.18 & $3.04 \mathrm{~b}$ & 9.68 \\
\hline & & Apical & - & 0.2 & 12 & 0.6 & 30 & 40.4 & 1.95 & 27.3 & 0.19 & $3.27 \mathrm{a}$ & 8.43 \\
\hline \multirow{4}{*}{80} & \multirow[t]{2}{*}{$\mathrm{Cv}$} & BG & $-1.18 b$ & $0.4 \mathrm{a}$ & $21 \mathrm{a}$ & $1.0 \mathrm{a}$ & 32 & $40.5 \mathrm{a}$ & 1.91 & 28.3 & 0.18 & 3.18 & 9.33 \\
\hline & & $\mathrm{CNN}$ & $-1.26 \mathrm{a}$ & $-0.9 b$ & $5 \mathrm{~b}$ & $0.2 \mathrm{~b}$ & 12 & $38.9 \mathrm{~b}$ & 1.95 & 27.2 & 0.18 & 3.13 & 8.78 \\
\hline & \multirow[t]{2}{*}{ Treatment } & $-\mathrm{UV}$ & -1.21 & -0.6 & 10 & 0.4 & 9 & $39.1 \mathrm{~b}$ & 1.95 & 28.5 & 0.16 & $3.01 \mathrm{~b}$ & $9.88 \mathrm{a}$ \\
\hline & & $\mathrm{C}$ & -1.23 & 0.1 & 16 & 0.8 & 35 & $40.4 \mathrm{a}$ & 1.91 & 27.0 & 0.20 & $3.31 \mathrm{a}$ & $8.23 \mathrm{~b}$ \\
\hline
\end{tabular}


TABLE 1 (CONTINUED)

\begin{tabular}{|c|c|c|c|c|c|c|c|c|c|c|c|c|c|}
\hline $\begin{array}{l}\mathrm{BBCH} \\
\text { stage }\end{array}$ & \multicolumn{2}{|l|}{ Main effect } & $\Psi_{\text {Stem }}$ & Pn & $\mathrm{g}_{\mathrm{s}}$ & $\mathrm{T}$ & WUEi & $\mathrm{T}_{\text {leaf }}$ & VPD & CHL & ANT & FLA & NBI \\
\hline \multirow{9}{*}{ p-value } & \multicolumn{2}{|l|}{$\mathrm{P}_{\text {(level) }}$} & - & 0.074 & 0.835 & 0.931 & 0.311 & 0.283 & 0.525 & 0.410 & 0.563 & 0.043 & 0.072 \\
\hline & & 0.024 & 0.005 & 0.006 & 0.005 & 0.224 & 0.001 & 0.397 & 0.321 & 0.746 & 0.621 & 0.425 \\
\hline & \multicolumn{2}{|l|}{$\mathrm{P}_{\text {(treatment) }}$} & - & 0.701 & 0.272 & 0.126 & 0.132 & 0.003 & 0.399 & 0.192 & 0.033 & 0.011 & 0.019 \\
\hline & \multicolumn{2}{|l|}{$\mathrm{P}_{\text {(level x cv) }}$} & - & 0.701 & 0.687 & 0.543 & 0.658 & 0.342 & 0.767 & 0.009 & 0.061 & 0.366 & 0.645 \\
\hline & \multicolumn{2}{|l|}{$\mathrm{P}_{\text {(level x treatment) }}$} & - & - & 0.062 & 0.044 & 0.063 & 0.410 & 0.180 & 0.241 & 0.603 & 0.171 & 0.526 \\
\hline & \multicolumn{2}{|c|}{$P_{(\mathrm{cv} x \text { treatment) }}$} & - & 0.853 & 0.642 & 0.811 & 0.931 & 0.861 & 0.699 & 0.209 & 0.400 & 0.463 & 0.796 \\
\hline & \multicolumn{2}{|c|}{$\mathrm{P}_{\text {(level x cv x treatment) }}$} & - & 0.885 & 0.233 & 0.158 & 0.624 & 0.200 & 0.745 & 0.150 & 0.055 & 0.176 & 0.076 \\
\hline & \multirow[t]{2}{*}{ Leaf } & Basal & - & 7.6 & 47 & 1.8 & 172 & 34.3 & 1.06 & 30.4 & 0.20 & 3.46 & 8.82 \\
\hline & & Apical & - & 7.2 & 43 & 1.6 & 180 & 34.6 & 1.11 & 31.1 & 0.17 & 3.37 & 9.29 \\
\hline \multirow{4}{*}{83} & \multirow[t]{2}{*}{$\mathrm{Cv}$} & $\mathrm{BG}$ & -0.88 & $8.7 \mathrm{a}$ & $53 \mathrm{a}$ & $1.9 \mathrm{a}$ & 175 & $33.7 \mathrm{~b}$ & 1.02 & 31.6 & 0.19 & $3.53 \mathrm{a}$ & 9.02 \\
\hline & & $\mathrm{CNN}$ & -0.88 & $6.2 \mathrm{~b}$ & $36 \mathrm{~b}$ & $1.5 \mathrm{~b}$ & 177 & $35.3 \mathrm{a}$ & 1.15 & 29.9 & 0.18 & $3.31 \mathrm{~b}$ & 9.09 \\
\hline & \multirow[t]{2}{*}{ Treatment } & $-\mathrm{UV}$ & -0.85 & $8.6 \mathrm{a}$ & 50 & 1.8 & 188 & $35.2 \mathrm{a}$ & 1.10 & $31.9 \mathrm{a}$ & 0.17 & 3.36 & $9.57 \mathrm{a}$ \\
\hline & & $\mathrm{C}$ & -0.92 & $6.2 \mathrm{~b}$ & 40 & 1.5 & 164 & $33.8 \mathrm{~b}$ & 1.07 & $29.6 \mathrm{~b}$ & 0.20 & 3.47 & $8.55 \mathrm{~b}$ \\
\hline \multirow[t]{9}{*}{ p-value } & \multicolumn{2}{|l|}{$\mathrm{P}_{\text {(level) }}$} & - & 0.663 & 0.435 & 0.535 & 0.629 & 0.439 & 0.278 & 0.528 & 0.213 & 0.327 & 0.197 \\
\hline & & 1.000 & 0.006 & 0.004 & 0.064 & 0.882 & 0.005 & 0.003 & 0.131 & 0.415 & 0.020 & 0.855 \\
\hline & \multicolumn{2}{|l|}{$\mathrm{P}_{\text {(treatment) }}$} & 0.373 & 0.008 & 0.086 & 0.020 & 0.150 & 0.001 & 0.374 & 0.054 & 0.092 & 0.220 & 0.008 \\
\hline & \multicolumn{2}{|l|}{$\mathrm{P}_{(\text {level x cv) }}$} &. & 0.404 & 0.599 & 0.754 & 0.294 & 0.935 & 0.752 & 0.478 & 0.508 & 0.855 & 0.704 \\
\hline & \multicolumn{2}{|l|}{$\mathrm{P}_{\text {(level } \mathrm{x} \text { treatment) }}$} & - & . & 0.109 & 0.232 & 0.819 & 0.639 & 0.132 & 0.498 & 0.401 & 0.694 & 0.724 \\
\hline & \multicolumn{2}{|c|}{$\mathrm{P}_{\text {(cv x treatment) }}$} & - & 0.650 & 0.964 & 0.799 & 0.741 & 0.330 & 0.629 & 0.406 & 0.829 & 0.231 & 0.984 \\
\hline & \multicolumn{2}{|c|}{$P_{\text {(level x cv x treatment) }}$} & - & - & 0.752 & 0.666 & 0.474 & 0.639 & 0.169 & 0.308 & 0.304 & 0.821 & 0.444 \\
\hline & \multirow[t]{2}{*}{ Leaf } & Basal & - & $7.5 \mathrm{~b}$ & $39 \mathrm{~b}$ & $1.7 \mathrm{~b}$ & 206 & 36.0 & 0.68 & - & - & - & - \\
\hline & & Apical & - & $10.8 \mathrm{a}$ & $56 \mathrm{a}$ & $2.4 \mathrm{a}$ & 206 & 36.5 & 0.63 & - & - & - & - \\
\hline \multirow{4}{*}{85} & \multirow[t]{2}{*}{$\mathrm{Cv}$} & BG & -1.29 & $10.7 \mathrm{a}$ & $59 \mathrm{a}$ & $2.5 \mathrm{a}$ & $189 \mathrm{~b}$ & $36.8 \mathrm{a}$ & 0.68 & - & - & - & - \\
\hline & & $\mathrm{CNN}$ & -1.27 & $7.6 \mathrm{~b}$ & $36 \mathrm{~b}$ & $1.6 \mathrm{~b}$ & $224 \mathrm{a}$ & $35.8 \mathrm{~b}$ & 0.63 & - & - & - & - \\
\hline & \multirow[t]{2}{*}{ Treatment } & $-U V$ & -1.25 & $10.5 \mathrm{a}$ & $56 \mathrm{~b}$ & $2.4 \mathrm{a}$ & 192 & 36.3 & 0.67 & - & - & - & - \\
\hline & & $\mathrm{C}$ & -1.31 & $7.8 \mathrm{~b}$ & $39 \mathrm{a}$ & $1.79 \mathrm{~b}$ & 220 & 36.25 & 0.64 & - & - & - & - \\
\hline$p$-value & $P_{\text {(level) }}$ & & - & 0.005 & 0.002 & 0.004 & 0.976 & 0.176 & 0.236 & - & - & - & - \\
\hline & $\mathrm{P}_{(\mathrm{cv})}$ & & 0.694 & 0.005 & 0.001 & 0.001 & 0.019 & 0.012 & 0.210 & - & - & - & - \\
\hline & $\mathrm{P}_{\text {(treatment) }}$ & & 0.369 & 0.001 & 0.002 & 0.011 & 0.061 & 1.000 & 0.414 & - & - & - & - \\
\hline & $\mathrm{P}_{\text {(level x cv) }}$ & & - & 0.818 & 0.622 & 0.750 & 0.363 & 1.000 & 0.873 & - & - & - & - \\
\hline & $\mathrm{P}_{\text {(level x treatment) }}$ & & - & - & 0.166 & 0.439 & 0.296 & 0.176 & 0.530 & - & - & - & - \\
\hline & $\mathrm{P}_{\text {(cv x treatment) }}$ & & - & 0.895 & 0.784 & 0.572 & 0.161 & 0.001 & 0.348 & - & - & - & - \\
\hline & $\mathrm{P}_{\text {(level } \mathrm{x} \text { cv } \mathrm{x} \text { treatr }}$ & & - & - & 0.742 & 0.955 & 0.230 & 1.000 & 0.304 & - & - & - & - \\
\hline
\end{tabular}

varieties, with the Cannonau gs averaging $20 \mathrm{mmol} / \mathrm{m}^{2} / \mathrm{s}$ less than that of Bovale grande. In the following measurements, significant differences in net assimilation and transpiration rates were observed, firstly among varieties $(\mathrm{BBCH}$ stage 80 ), with higher $\mathrm{Pn}, \mathrm{g}_{\mathrm{s}}$ and $\mathrm{T}$ values in Bovale grande (Table 1). A tighter stomatal closure in Cannonau leaves was observed over the whole experiment, and the pattern of the differences among varieties concerning leaf gas exchange rates was maintained across the season. At stage 80, when plant water status decreased to about -1.2 MPa and the air temperature reached the highest values, stomatal closure was much stronger in the Cannonau leaves, leading to Pn values lower than zero and almost zero transpiration. In Bovale grande, Pn was reduced to values close to zero, yet the higher 
stomatal aperture in this cultivar led to higher $\mathrm{T}$ compared to that of Cannonau. In addition, the apical Bovale grande leaves under the -UV treatment presented higher T, while in Cannonau those leaves had the lowest average $\mathrm{T}$ values.

Also, the leaf temperature was different between cultivars along the season. When lower plant water potential values were reached, Bovale grande evidenced the highest $\mathrm{T}_{\text {leaf }}$, while under mild water deficit (first and third measurements), a higher $\mathrm{T}_{\text {leaf }}$ was recorded in Cannonau. At véraison and ripening (stages 80 and 83 ), the maximum air temperature remained under $30^{\circ} \mathrm{C}$, and $\mathrm{Pn}$ and $\mathrm{T}$ reached values similar to those recorded at the beginning of the experiment (Table 1). Also, $g_{s}$ recovered, although the values remained lower than that on the first measurement date. At this stage, highly significant differences were observed among varieties and treatments, with higher leaf gas exchange rates being observed in the -UV leaves (Table 1). Despite the significantly higher temperature of the -UV canopies (Fig. S3), these plants were able to keep a lower $\mathrm{T}_{\text {leaf }}$ at mid-morning compared to the control plants directly exposed to solar radiation until véraison. During the last measurement, the $\mathrm{T}_{\text {leaf }}$ in the two treatments was similar.

No significant differences in intrinsic water-use efficiency were observed among cultivars, varieties and leaf levels (Table 1). However, Cannonau exhibited higher stomatal control over a range of VPD from 1 to $2 \mathrm{kPa}$, and a curvilinear relationship was observed between WUEi and gs, with lower WUEi from 0 to $100 \mathrm{mmol} / \mathrm{m}^{2} \mathrm{~s}$ of gs in the two varieties (Fig. 5). For the environmental conditions of the season, higher values of WUEi were achieved with lower gs in Cannonau, but at the expense of significantly lower An compared to Bovale grande, which showed higher increments in assimilation rate.

\section{Primary photochemistry and energy dissipation of PSII}

As far as PSII activity is concerned, no significant changes in most of the direct chlorophyll fluorescence variables were observed during the first days of the trial (BBCH 75), except for a decrease in the quantum yield for electron transport $\left(\varphi_{\mathrm{EO}}\right)$ in -UV plants (Fig. 6; Table S3). After 20 days of UV-blocking treatment (stage 80), the differences in PSII activity among treatments became highly significant. In the -UV leaves, the heat and water stress conditions $\left(\mathrm{T}_{\text {leaf }}\right.$ of $39^{\circ} \mathrm{C}$ to $40^{\circ} \mathrm{C},-1.2 \mathrm{MPa}$ of $\left.\Psi_{\mathrm{Stem}}\right)$ induced a lower maximum quantum yield for primary photochemistry $\left(\varphi_{\mathrm{P}_{0}}\right)$, and for electron transport $\left(\varphi_{\mathrm{Eo}}\right)$, water-splitting efficiency $\left(\mathrm{F}_{\mathrm{v}} / \mathrm{F}_{\mathrm{o}}\right)$ and density of the reaction centres $\left(\mathrm{RC}_{\mathrm{QA}}\right)$, which are indicative of photoinhibition. Meanwhile, the control plants did not show increased energy dissipation $\left(\varphi_{\mathrm{DI}}\right)$, and the quantum yield of PSII remained at high values. Nevertheless, when calculating the differences, $1 / \mathrm{F}_{\mathrm{o}}-1 / \mathrm{F}_{\mathrm{m}}$, an opposite pattern was observed among varieties from the second measurement in Fig. 7, in both the basal and apical leaves: Cannonau presented a decreasing trend, in contrast with the increasing trend of Bovale grande.

The PSII in younger adult leaves on the apical part of the shoot was able to perform better than in the basal leaves only at the cluster closure stage, when water deficit and heat stress became stronger (showing higher $\varphi_{\mathrm{Po}}, \mathrm{F}_{\mathrm{v}} / \mathrm{F}_{\mathrm{o}}$, and $\mathrm{RC}_{\mathrm{QA}}$ and lower average $\varphi_{\mathrm{DIo}}$ values). However, in the following stages, the differences in the effects of main leaf level became not significant. Despite the tight stomatal closure of Cannonau leaves, a cultivar effect on PSII activity was not statistically evident. In contrast, the effect of treatment remained highly significant and a recovery of $\varphi_{\mathrm{P}_{0}}, \mathrm{~F}_{\mathrm{v}} / \mathrm{F}_{\mathrm{o}}, \varphi_{\mathrm{Eo}}$ and $\mathrm{RC}_{\mathrm{QA}}$ was observed in the average values of the $-\mathrm{UV}$ leaves at véraison (BBCH 83). The recovery of $\varphi_{\mathrm{Eo}}$ and $\mathrm{RC}_{\mathrm{QA}}$ was slower in the -UV Bovale grande apical leaves, and was observed only at ripening (Fig. 6). At this stage, no significant differences in the primary photochemistry and energy dissipation parameters of PSII were observed among the varieties, treatments or leaf levels, but an interactive cultivar-treatment effect on $\varphi_{\mathrm{Eo}}$ was observed, with higher values in Bovale grande -UV and lower levels in the Cannonau Control (Table S3). A similar trend was observed in $\mathrm{RC}_{\mathrm{QA}}$, but it was not statistically significant (Fig. 6).

\section{Leaf chlorophyll, anthocyanin, flavonol and nitrogen balance}

Initially, the estimation of leaf pigments at $\mathrm{BBCH}$ stage 75 measured with Dualex scientific+ indicated a higher anthocyanin content in Cannonau leaves compared to Bovale grande, while significant differences were observed only among treatments in the following measurements (Table 1; Fig. 7). The control plant presented significantly higher values for the anthocyanin index in both varieties. At véraison (stage 83), a higher anthocyanin index was still observed in the Bovale grande control leaves, but the differences among treatments in Cannonau were reduced (Fig. 7). Regarding the flavonol index, the main differences were detected at stage 80 , with lower values being observed in -UV and in the basal leaves of the two cultivars. By véraison, the flavonol index had already increased in -UV to the values measured in the control leaves. As far as the chlorophyll index is concerned, the two varieties presented slightly different trends before veraison, with higher values in the leaves at the basal part of the shoot compared to those at the apex in Cannonau; the opposite behaviour was observed in Bovale grande. At véraison, the $-\mathrm{UV}$ leaves presented a higher, yet not statistically significant, chlorophyll index. The treatment effect led to a lower nitrogen balance index in the control plants. This was observed from the first estimation and became increasingly significant as the experiment continued.

\section{Variation of primary leaf photochemistry and gas exchange activity}

To determine possible correlations among leaf gas exchange performance, PSII activity, plant water status and the observed variations in the level of key leaf pigments, multifactor analysis (MFA) and orthogonal partial least squares discriminant analysis (OPLS-DA) were carried out (Fig. 8; Table S5). The focus was on the variables for which significant main effects of treatment and cultivar were detected across the season (Tables 1 and S3). Overall, $64 \%$ of the variation in leaf gas exchange, primary photochemistry and pigment level variables were explained by two main factors. The variables derived from chlorophyll fluorescence were highly correlated with the first factor, which can be identified by light conditions and which primarily governs the lightdependent photosynthesis step. In contrast, leaf gas exchange 

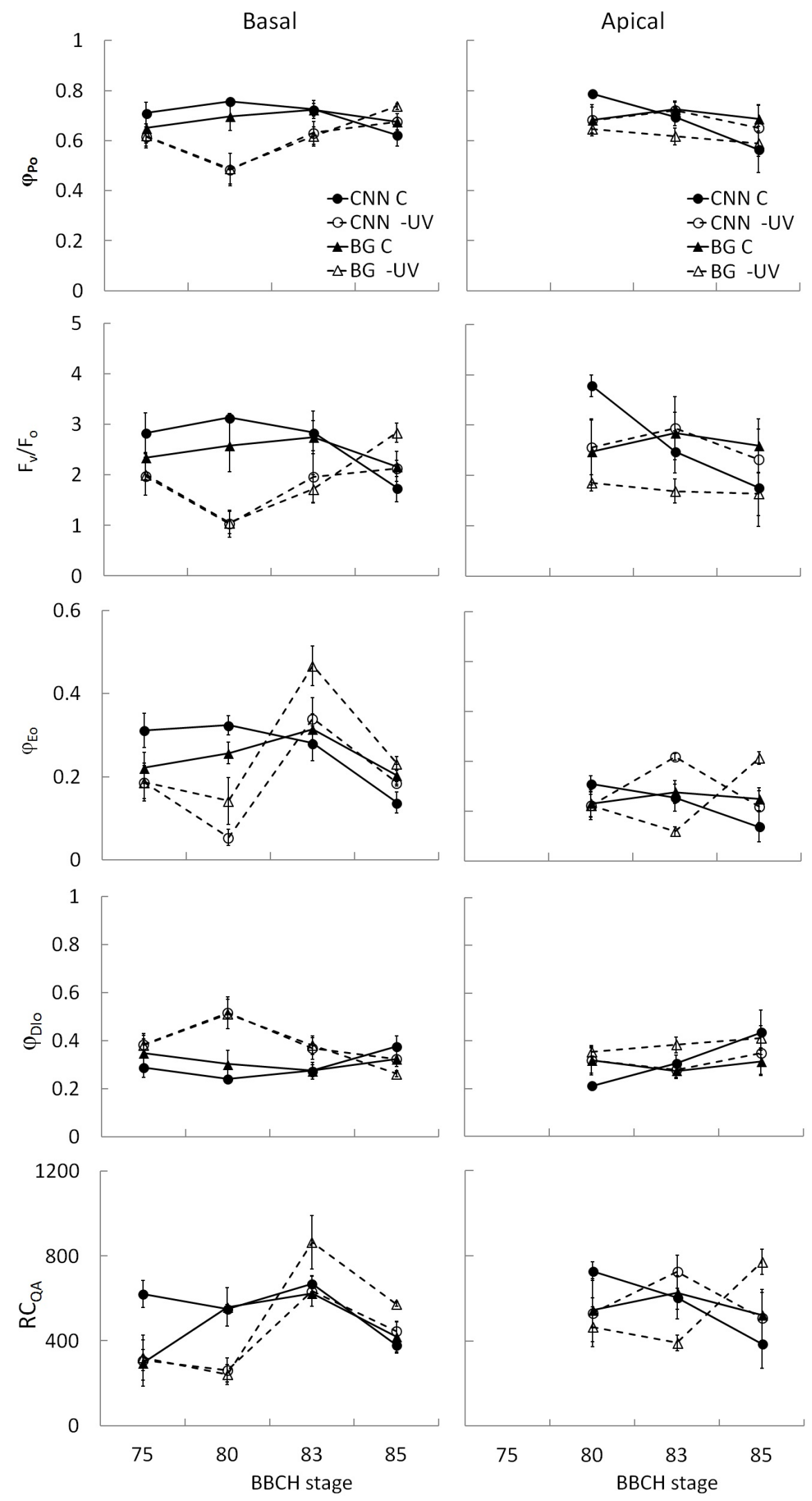

FIGURE 6

Primary photochemical performances of the PSII in Bovale grande (BG) and Cannonau (CNN) basal and apical main adult leaves inside the UV-screening filter (-UV) and outside (Control, C) during midmorning in clear sky days. Maximum yield of primary photochemistry of PSII $\left(\varphi_{\mathrm{P}_{\mathrm{o}}}\right)$ water slitting efficiency $\left(\mathrm{F}_{\mathrm{v}} / \mathrm{F}_{\mathrm{o}}\right)$, quantum yield for electron transport $\left(\varphi_{\mathrm{Eo}}\right)$ quantum yield for energy dissipation $\left(\varphi_{\mathrm{DI}}\right)$ and density of reaction centers $\left(\mathrm{RC}_{\mathrm{QA}}\right)$. Mean $(\mathrm{n}=6) \pm \mathrm{SE}$. 

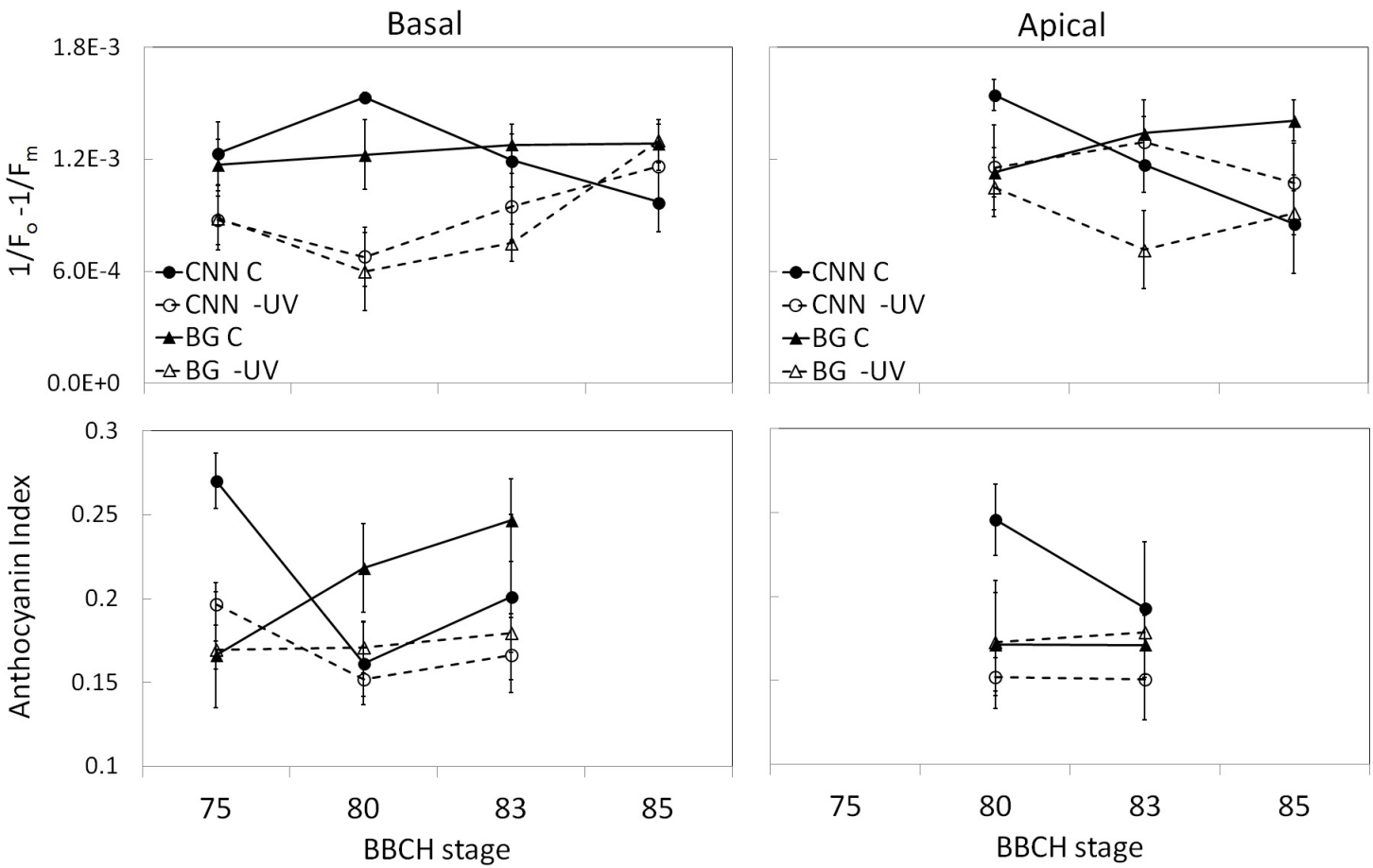

FIGURE 7

Functional PSII units parameter $\left(1 / \mathrm{F}_{\mathrm{o}}-1 / \mathrm{F}_{\mathrm{m}}\right)$ (a) and Anthocyanin Index (b) in Bovale grande (BG) and Cannonau (CNN) basal and apical main adult leaves outside (Control, C) and inside the UV-screening filter (-UV) during midmorning in clear sky days. Mean $(\mathrm{n}=6) \pm \mathrm{SE}$.
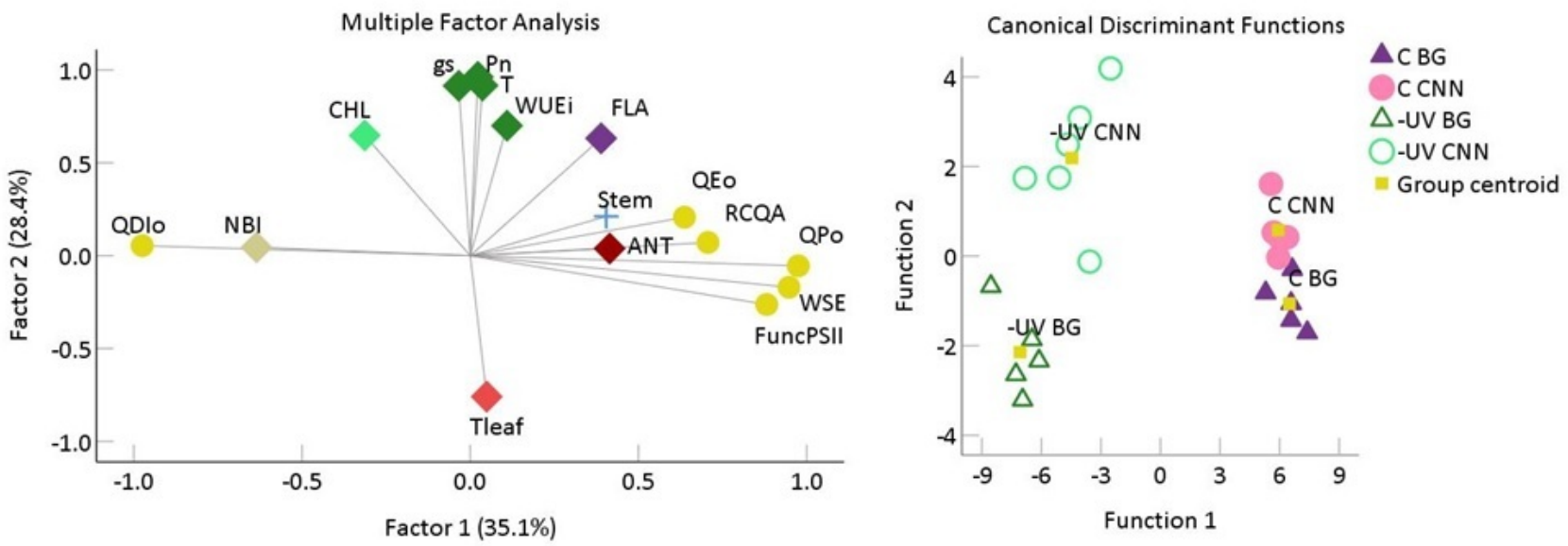

FIGURE 8

Multi-factor analysis (a) and orthogonal partial least square discriminant analysis (b) score plots of leaf gas exchange, stem water potential, primary photochemical performances of the PSII and leaf pigment indexes during the experimental season (from $\mathrm{BBCH}$ stage 75 to 85 ) taking into account the whole leaf level, cultivar and treatments. The analyses were performed after scaling and normalizing the input variables: stem water potential (Stem), leaf temperature (Tleaf), net photosynthesis $(\mathrm{Pn})$, stomatal conductance $(\mathrm{gs})$, transpiration $(\mathrm{T})$ rates, intrinsic water use efficiency (WUEi), maximum yield of primary photochemistry of PSII (QPo) water slitting efficiency (WSE), quantum yield for electron transport (QEo) quantum yield for energy dissipation (QDIo), PSII functional units (funcPSII), density of reaction centers (RCQA), anthocyanin (ANT), flavonol (FLA), chlorophyll (CHL) and nitrogen balance (NBI) indexes. Primary photochemical variables, that represent the performances of light-dependent photosynthetic step, are presented in yellow coloured circles. Green rhombus symbolize leaf gas exchange variables. Leaf temperature is represented by red rhombus and violet, red, green and grey squares correspond respectively to flavonol, anthocyanin, chlorophyll and nitrogen balance indexes. 
and leaf temperature varied according to the second factor, which is associated with temperature, specifically with the well known temperature-dependent regulation of maximum leaf gas exchange performance. Furthermore, leaf pigment levels were influenced, to a lesser extent, by the two factors extracted. The OPLS-DA separated the four treatment $\mathrm{x}$ cultivar groups according to two significant functions. The independent variable that firstly fitted to parsimoniously classify the four groups was $\Psi_{\text {Stem }}$. The second function subsequently discriminated the groups according to the following variables: PSII functional units, CHL, NBI, gs, T and $\mathrm{T}_{\text {leaf }}$ A third discriminant function included Pn, ANT and FLA and other PSII photochemistry variables, adding even further distinction among groups when compared to the first two functions (Fig. 8, Table S4). When MFA was applied exclusively to control the leaves, both the photochemical variables and leaf gas exchange parameters were correlated the most with factor 1 (Fig. 9). The ANT, NBI and CHL indexes and $\Psi_{\text {Stem }}$ correlated the most with factor 2 , and $\varphi_{\mathrm{Eo}}$ and $\mathrm{T}$ also correlated with factor 2 to a significant degree. Under the -UV treatment, gas exchange in the leaf and plant water status showed a strong correlation with factor 2, along with $\mathrm{T}_{\text {leaf }}$ (in the opposite direction), while the primary photochemistry of the leaf, NBI and ANT were mainly related to factor 1 . In this case, FLA correlated similarly with the two main factors. When MFA was performed considering the two varieties separately, the variance in primary photochemistry of the leaf again was explained by factor 1, and the performance of gas exchange in the leaf and the temperature were related to factor 2. In Bovale grande, the influence of factor 1 was higher and related more closely to ANT, while FLA correlated with factor 2. In Cannonau, the influence of factor 2 on the gas exchange performance and $\mathrm{T}_{\text {leaf }}$ was slightly higher; a lower correlation of factor 1 was found with ANT and $\Psi_{\text {Stem }}$. Overall, as expected, the quantum yield for energy dissipation varied in the opposite direction of the maximum quantum yield for primary photochemistry, the density of the reaction centres in PSII, electron transport and water-splitting efficiency, while the maximum gas exchange in the leaf correlated negatively with leaf temperature (Fig. 9; Table S5).

\section{DISCUSSION}

\section{Treatment-dependent responses}

During the study season, air and canopy temperature reached very high values $\left(>35^{\circ} \mathrm{C}\right)$ from midmorning until afternoon on several days. Under such conditions, photosynthetic assimilation is reduced or even shut down and, consequently, vegetative growth is limited (Kadir et al., 2007). Some studies have also reported decreases in canopy growth
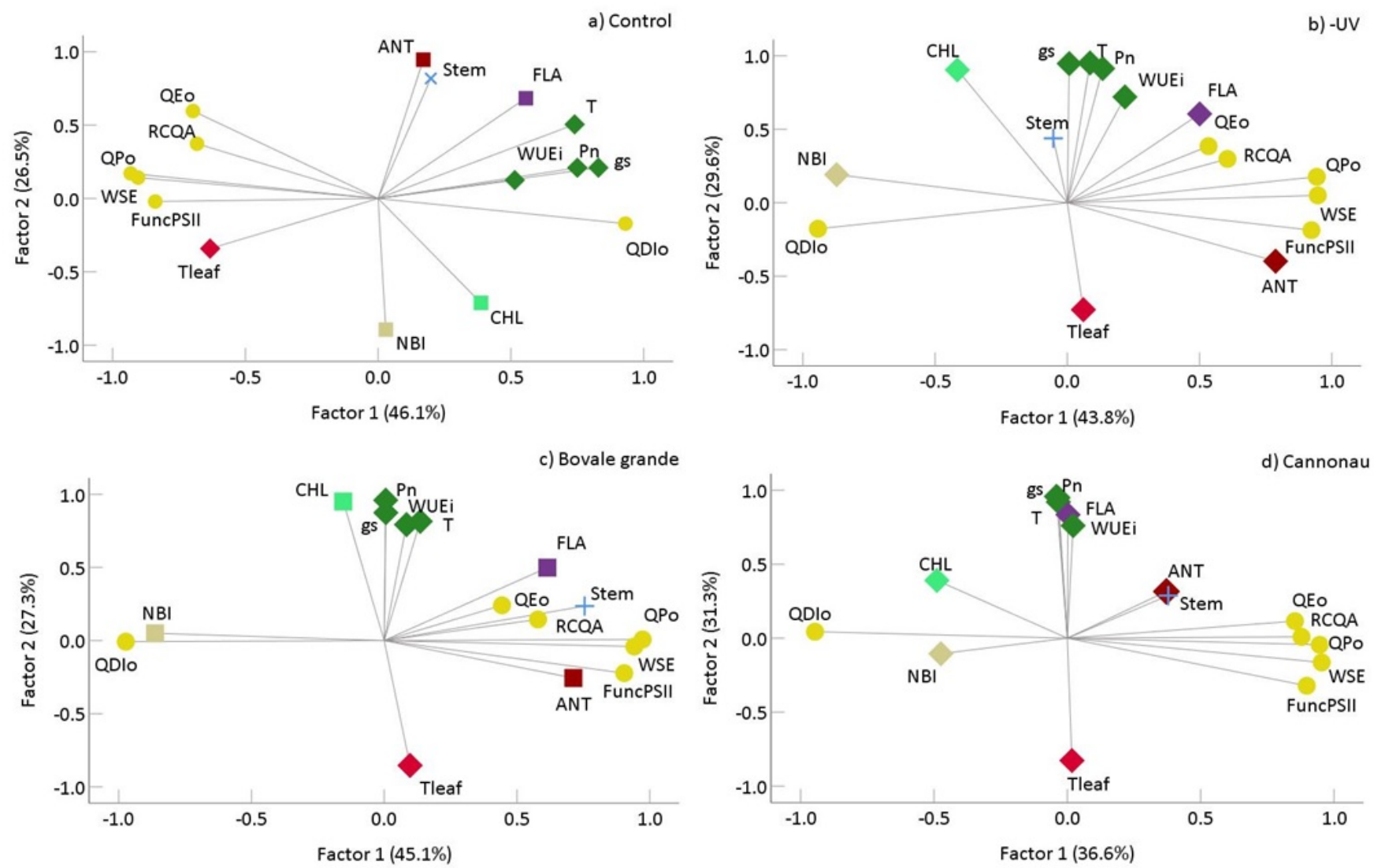

FIGURE 9

Multi-factor analysis score plots of scaled and normalized data of leaf gas exchange, stem water potential, primary photochemical performances of PSII and leaf pigment indexes during the experimental season (from BBCH stage 75 to 85 ) taking separately into account treatment ( $\mathrm{a}$ and $\mathrm{b}$ ) and cultivar ( $\mathrm{c}$ and $\mathrm{d}$ ) effects. 
caused by high UV-B radiation levels (Berli et al., 2010; Doupis et al., 2011). In our study, light treatment did not induce significant differences in the development of total leaf area, and mild to moderate water stress imposed by deficit irrigation allowed the leaf area to keep growing, also in the -UV plants, although subjected to higher heat stress.

The main differences between the two treatments were found in maximum leaf gas exchange and PSII performance. Despite the higher temperature inside the tunnels, the UV-blocking treatment resulted in a higher maximum photosynthetic rate but lower primary photochemical efficiency. These plants invested in efficient heat dissipation, avoiding further increases in temperature. Though photoinhibition, the limitations of PSII were evident under $-\mathrm{UV}$, and the plants were able to restore high Pn, T and gs rates (Lovisolo et al., 2010). Although the-UV plants were subjected to significantly higher heat stress compared to the control, sufficient PAR light $\left(\geq 1000 \mu \mathrm{mol} / \mathrm{m}^{2} \mathrm{~s}\right)$ conditions and the moderate water status imposed on both varieties enabled a complete recovery of the PSII apparatus, and even higher PSII activity and maximum net assimilation by the end of the season. In contrast, gas exchange rates in the leaves of plants exposed directly to solar UV radiation became more limited as the season advanced, also showing a higher correlation with the light conditions (factor 1 in Fig. 9a) and with the primary photochemical variables compared to the $-\mathrm{UV}$ plants. The high $\varphi_{\mathrm{Po}}$ in the control leaves during the first stages of the trial is in agreement with a lower photoinactivation of PSII grapevines acclimated to environments with high levels of light. Nevertheless, the decreases in $\mathrm{F}_{\mathrm{v}} / \mathrm{F}_{\mathrm{o}}, \varphi_{\mathrm{Eo}}$ and $\mathrm{RC}_{\mathrm{QA}}$ from véraison to harvest suggest photoinhibition and a reduced recovery capacity of PSII in UV-exposed plants. In fact, previous works by Flexas et al. (2001) indicates that, in grapevines grown in Mediterranean areas that are acclimated to high levels of light, the values of $\varphi_{\mathrm{Po}}$ may give the impression of a high quantum yield when in fact a large portion of the functional PSII units may be inactivated.

Moreover, the fact that the $-\mathrm{UV}$ plants were able to recover PSII activity, and reach even higher midmorning leaf gas exchange rates during ripening compared to the control plants, is consistent with a higher acclimation capacity to heat than to UV light stress. High recovery capacity under heat stress was also demonstrated by the sharp increase in the maximum quantum yield for electron transport $\left(\varphi_{\mathrm{Eo}}\right)$ and the density of the reaction centres $\left(\mathrm{RC}_{\mathrm{QA}}\right)$ observed in the UV leaves at véraison, when temperature decreased and mild plant water status was restored by an increase in re-watering supply.

Martínez-Lüscher et al. (2013) reported a high acclimation to UV-B radiation in Tempranillo grapevines under optimal thermal conditions $\left(25^{\circ} \mathrm{C} / 15^{\circ} \mathrm{C}\right.$ day/night temperatures). These authors did not observe a significant reduction in maximum PSII efficiency, despite the reduction in gas exchange rates in the leaves. In fact, small reductions in photosynthesis may be counterbalanced by the accumulation of phenolic compounds in the leaves (Del-Castillo-Alonso et al., 2016). The multi-factor analysis applied to the whole data separated variations in leaf gas exchange from direct primary photochemistry; however, under the high direct solar radiation conditions of the control plants, gas exchange performance in the leaves was affected the most by sunlight and was linked to the performance of the light-dependent photosynthesis step. Generally, leaf temperature of the $-U V$ plants was highly correlated with chlorophyll fluorescence parameters, namely PSII activity, photoinhibition and recovery, as well as with the chlorophyll index. In the control plants, the weak relationship among the temperature, net assimilation and primary photochemistry variables and chlorophyll can be ascribed to the interposition of the UVscreening photoprotection effect of leaf phenolics.

Higher values of the two phenolic compounds in the UVexposed leaves were statistically significant at the beginning of véraison, while chlorophyll and nitrogen balance indexes became higher under the UV-blocking filter. Grifoni et al. (2016), using a similar optical instrument in grapevine leaves, also observed decreases in the accumulation of flavonols in the absence of UV radiation, along with increased accumulation when the leaves were re-exposed to direct solar radiation. In our experiment, we found a reduction in the UV-screening photoprotection capacity due to the decrease in anthocyanin content in the leaf epidermis, which is consistent with the decrease in PSII activity in the control plants during the season and helps to explain the loss of PSII functional units under conditions of high insolation. This was particularly evident in the cultivar Cannonau, in which the total anthocyanin contents are known to be highly sensitive to elevated temperature (Fernandes de Oliveira et al., 2017).

\section{Variety-dependent responses}

Although Bovale grande and Cannonau showed different balances in primary and lateral leaf area growth, the two varieties reached similar total leaf area under the control and -UV treatments. The differences in canopy density did not induce significant differences between varieties in light transmission into the canopy, probably because the higher lateral leaf area of Cannonau was composed of small leaves that allowed sun-flecks to penetrate into the inner canopy layers.

Bovale grande and Cannonau plants exhibited differences in maximum leaf gas exchange rates, but similar primary photochemistry efficiency, as atmospheric demand and water deficit increased. As expected, the Cannonau plants exhibited typical isohydric behaviour (Fernandes de Oliveira et al. 2013), characterised by tighter stomatal control over transpiration (gs remaining about $20 \mathrm{mmol} / \mathrm{m}^{2} \mathrm{~s}$ lower, ranging from $63 \mathrm{mmol} / \mathrm{m}^{2} \mathrm{~s}$ in the first measurement to 5 $\mathrm{mmol} / \mathrm{m}^{2} \mathrm{~s}$ when the lowest $\Psi_{\text {Stem }}$ was recorded) compared to that of Bovale grande (with an average gs of $82 \mathrm{mmol} / \mathrm{m}^{2} \mathrm{~s}$ on the first date and $21 \mathrm{mmol} / \mathrm{m}^{2} \mathrm{~s}$ when the vines reached a lower $\left.\Psi_{\text {Stem }}\right)$. However, the leaves of both varieties balanced the daily maximum gas exchange in the leaves according to the environmental conditions, being able to display similar intrinsic water-use efficiency and stem water content. They also adjusted their maximum photosynthetic performance to the environmental stresses (high UV light, heat and moderate water deficit), following the same pattern and recovering similarly during the season. In Cannonau, this was achieved at the expense of a lower maximum assimilation rate (about 
2 to $3 \mu \mathrm{mol} / \mathrm{m}^{2} \mathrm{~s}$ less under mild water and heat stress to $1.3 \mu \mathrm{mol} / \mathrm{m}^{2} / \mathrm{s}$ less with moderate water and heat stress compared to Bovale grande), indicating that, under mild to moderate water deficit and elevated temperatures, the nearanisohydric behaviour of Bovale grande can result in a more efficient strategy from a crop-productivity perspective, as also suggested by other authors (Sade et al., 2012).

The long duration of heat stress, combined with moderate water deficit, led to a substantial decrease of the maximum leaf photosynthetic and transpiration rates in both varieties. Whenever the temperature reached $40^{\circ} \mathrm{C}$, the assimilation rate was promptly reduced, and further transpiration losses and damage to the photosynthetic apparatus were avoided by stricter stomatal control, a coordinated reduction in PSII activity and an increase in energy dissipation. Luo et al. (2011), who studied heat stress effects on the primary photochemistry of young potted Zuoyouhong grapevines (Vitis amurensis L.) grown under controlled day/night temperature cycles and about $1000 \mu \mathrm{mol} \mathrm{m} \mathrm{m}^{-2} \mathrm{~s}^{-1}$ maximum PAR, observed a significant inhibition in net assimilation rate and stomatal conductance only when the temperature reached $40^{\circ} \mathrm{C}$ and $45^{\circ} \mathrm{C}$.

Regardless of the light treatment, the reduction of stomatal aperture under tougher temperature and water stress conditions in our experiment $\left(\mathrm{T}_{\text {leaf }}\right.$ of $40^{\circ} \mathrm{C}$ and moderate water deficit) differed in the two varieties. The lower gs of Cannonau led to lower evaporative cooling (from 0.4 to 0.9 $\mathrm{mmol} / \mathrm{m}^{2} / \mathrm{s}$ lower T). However, this was not followed by a significantly different level of primary photochemistry quantum yield and energy dissipation efficiency among the varieties. Nevertheless, a higher water-splitting efficiency of PSII and a faster recovery of the PSII reaction centre was observed in Cannonau when thermal and water stress increased, which led to stomatal closure. Kadir et al. (2007), on the other hand, when studying the effect of sudden versus gradual heat stress on the primary photochemistry of photosynthesis in the leaf in two varieties, namely Vignoles and Cynthiana, observed that a different grade of damage to PSII, expressed by the percentage decrease in $\varphi_{\mathrm{Po}}$, was caused by heat stress, regardless of the duration of the heat shock. These authors also reported greater recovery of PSII in one of the two varieties. Such varietal difference was not observed in our study, only a slower increase in the $\varphi_{\mathrm{Eo}}$ and $\mathrm{RC}_{\mathrm{QA}}$ values in the Bovale grande - UV apical leaves by véraison, and this had already recovered at the beginning of ripening.

When there was a higher intensity of solar radiation and evaporative demand, the two varieties were exposed to high natural and gradual heat, light and water stresses. The accumulated exposure of the canopy to temperatures over $35^{\circ} \mathrm{C}$ was about 10 days in $-\mathrm{UV}$, and did not exceed one day in the control plants. Furthermore, the $\mathrm{T}_{\text {canopy }}$ reached $40^{\circ} \mathrm{C}$ only in the $-\mathrm{UV}$-treated plants and for a maximum duration of one day. Taking into consideration previous work on photosynthetic regulation in grapevines subjected to increasing water stress and high evaporative demand (Flexas \& Medrano, 2002; Bertamini \& Nedunchezhian, 2003; Luo et al., 2011), we can affirm that both Cannonau and Bovale grande were able to respond efficiently to heat stress and water deficit.
The results also show that the high leaf gas exchange performance was closely related to leaf temperature, while the photochemical performance was related less to the temperature condition of the leaves in both the near-isohydric and the near-anisohydric varieties. Also, the relationship between plant water status and the light-dependent photosynthetic step was much weaker in the Cannonau leaves than in Bovale grande (Fig. 9c and 9d). These findings are in accordance with the tighter stomatal control and the higher efficiency of hydraulic regulation mechanisms governing leaf conductance and water losses in Cannonau, namely leaf architecture and anatomy, hydraulic conductance and cell wall elasticity (Chouzouri \& Schultz, 2005; Hugalde \& Vila, 2018). Nevertheless, the two varieties were able to maintain similar intrinsic water-use efficiency and plant water status under both UV and heat stress conditions. The estimation of leaf metabolites showed evidence of seasonal differences among the varieties in the accumulation of UVscreening pigments during growth, firstly in anthocyanins and then in flavonols. Nevertheless, these differences did not induce changes in the nitrogen balance index. This result also suggests an important plasticity of the two cultivars in adapting to conditions of thermal and light stress without suffering a significant alteration in leaf nitrogen metabolism or without it affecting the integrity of the photosynthetic apparatus. The variation in both indexes of phenolics closely and positively followed the photochemical performance in Bovale grande, while in Cannonau the anthocyanin content in the leaves was somewhat related to primary photochemistry efficiency. Moreover, the contrasting trends between the varieties, both in PSII functional units and the anthocyanin index of the basal and apical Cannonau control leaves (Fig. 7), together with the increasing photoinhibition trend over the season, indicate that UV light exposure induced long-lasting photoinactivation of PSII in this variety. This result suggests that phenolic accumulation in the leaf epidermis may have functioned efficiently as a photoprotection mechanism in both varieties before véraison, but the higher sensitivity to anthocyanin degradation under elevated temperatures, previously observed in Cannonau berry skin (Fernandes de Oliveira \& Nieddu, 2016a), led to a loss in leaf photoprotection and photochemical reaction capacity under high solar UV light conditions. This finding was also supported by the multifactor analysis of variety effects (Fig. 9c and 9d), which showed that, in Bovale grande, the leaf primary photochemical performance varied positively with the anthocyanin index, while the variation in gas exchange was weakly related to this index. Besides, a weaker correlation between the anthocyanin index and leaf primary photochemistry and leaf gas exchange-related variables was observed in Cannonau. The flavonol index was affected less by temperature, showed lower variation between treatments and correlated with both photosynthetic and photochemical performance in Bovale grande, but only with the variation in leaf gas exchange in Cannonau. This result is consistent with the higher stability of flavonols under high sunlight and heat compared to anthocyanin. Such differences between the two phenols can also be associated with the predominant role of anthocyanins in red grape metabolism, since in white grape varieties flavol contents 
have been reported to increase under moderate water deficit and high sunlight conditions compared to well watered vines (Deluc et al., 2009; Fernandes de Oliveira et al., 2019).

\section{CONCLUSIONS}

The near-isohydric and near-anisohydric grapevines differed significantly in their acclimation responses to UV radiation under high evaporative demand, and mild to moderate water stress. Both varieties showed good leaf physiological performance and photochemical efficiency, together with a high recovery capacity of the photosynthetic apparatus upon intense solar radiation. Thus, no significant reductions in vegetative growth were observed, although Cannonau invested in lateral shoots, while Bovale grande was able to enhance its main shoot leaf area during the fruit-development stages. Natural UV radiation induced a stronger and longer negative impact on leaf physiological performance in both varieties. In fact, other than being distinguished by their water loss regulation mechanisms, the two varieties on trial were also separated according to the effects that UV exposure and heat stress induced in the regulation of photosynthetic and photochemical performance, as well as in leaf phenolics and the chlorophyll balance (Fig. 10). Besides for lower transpiration rates, lower net assimilation and recovery capacity after high heat stress were also detected in the near-isohydric Cannonau exposed to high natural UV levels. Among the photoprotective mechanisms underlying the high acclimation capacity, the accumulation of phenolic compounds plays a crucial role in grapevines. Varietal differences in the seasonal dynamics of pigment accumulation were evident in the main leaves of both the basal and apical shoots. In addition, Cannonau showed higher sensitivity to the thermal degradation of anthocyanins, which are major UV-screening phenolic compounds in red grapes. Despite these differences, both varieties were able to efficiently balance leaf water use and plant water status.

It is for these reasons that we can conclude that, when mild to moderate water stress thresholds are maintained, both Bovale grande and Cannonau show high acclimation to heat and UV light stresses. Furthermore, the impact of high UV radiation and elevated temperatures on photosynthetic capacity and photochemical performance of near-isohydric

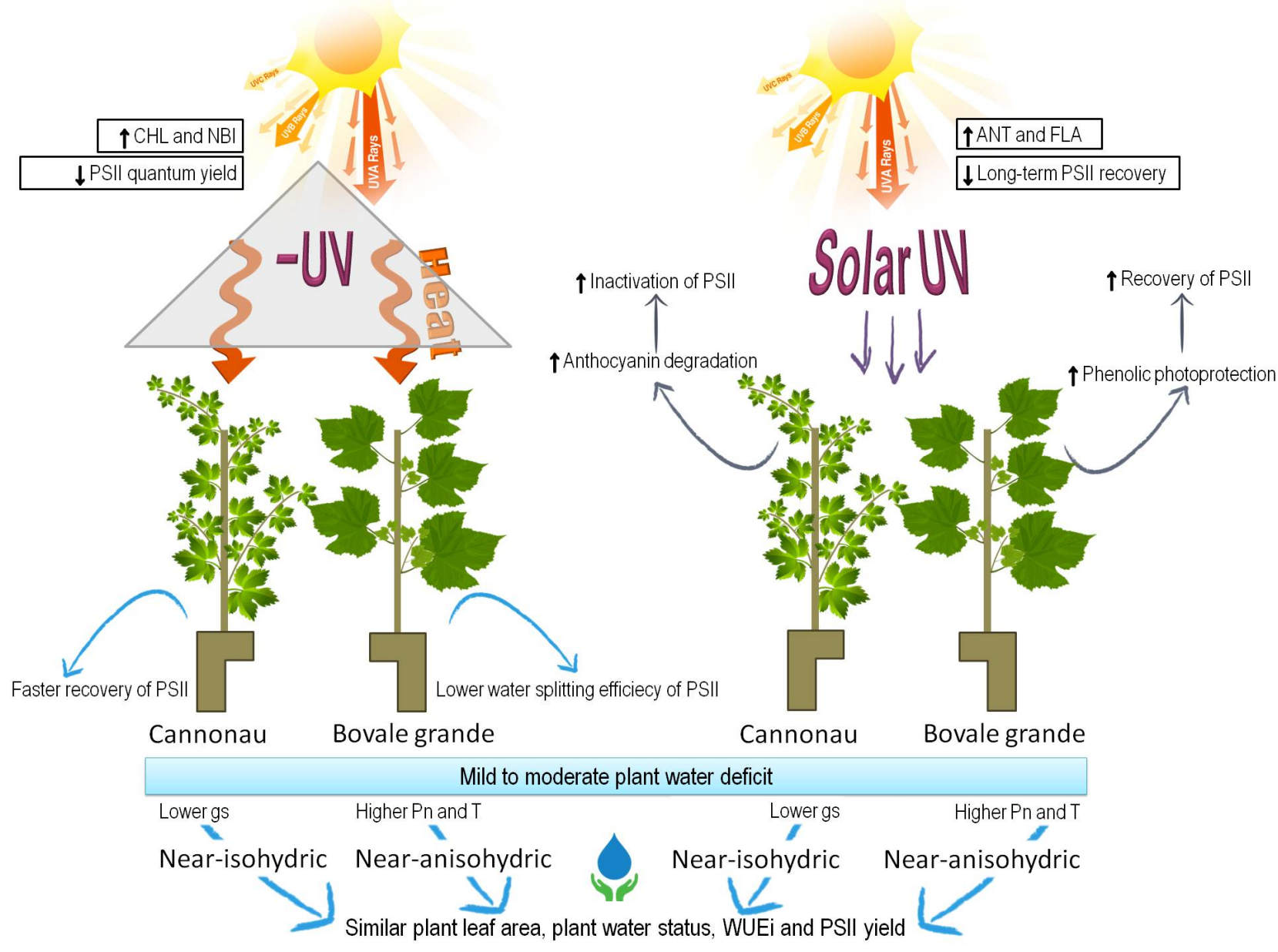

FIGURE 10

Conceptual representation of cultivar and treatment related responses concerning plant leaf area balance and water status, maximum leaf gas exchange and primary photochemistry efficiency and leaf pigment variation upon high solar UV and heat stress conditions of field-grown Bovale grande and Cannonau plants kept under mild to moderate water deficit. 
and anisohydric varieties depends on the perception and regulation mechanisms of each variety, including differences in leaf hydraulic properties and anatomic characteristics. However, it can also be affected by differences in phenolic accumulation dynamics and phenolic profiles. In this sense, agronomical practices that affect the synthesis and accumulation of leaf pigments can influence canopy acclimation to heat and conditions of high sunlight. Under Mediterranean conditions, the decisions concerning vineyard management, like the pruning system, the timing, frequency and intensity of canopy management operations, as well as the best irrigation system and scheduling, must take into consideration the need to avoid excessive sunlight exposure and long duration of elevated temperatures during the hot and dry season. Moreover, in such conditions, monitoring the canopy temperature may give an accurate indication of plant physiological status and water requirements for both near-isohydric and near-anisohydric varieties, since it is closely related to plant water status and, on the whole, to photo-assimilation performance during the growing season. Finally, using the new optical tools that allow for rapid and non-destructive estimation of leaf pigments, further research could be conducted, both in situ and in vivo, to provide new information on how and how fast grapevines can balance these key metabolites in their leaves in order to recover their photosynthetic and photochemical functionality. Such new knowledge will allow for a deeper understanding of short- and long-term response mechanisms, as well as of the degree of plasticity that different varieties may achieve under multiple stress conditions.

\section{APPENDIX A. SUPPLEMENTARY DATA}

Supplementary data associated with this article can be found in the online version.

\section{LITERATURE CITED}

Aeronautica Militare, 2017. Servizio Meteorologico Aeronautica Militare. Dati meteo. Online: http://clima.meteoam.it/_ [accessed 14 March 2017].

Alsina, M.M., Herralde, F., Aranda, X., Savé, R. \& Biel, C., 2007. Water relations and vulnerability to embolism are not related: Experiments with eight grapevine cultivars. Vitis 46, 1-6.

Anderson, K. \& Aryal, N.R., 2013. Which winegrape varieties are grown where? A global empirical picture. The University of Adelaide Press, Adelaide.

Bais, A.F., McKenzie, R.L., Bernhard, G., Aucamp, P.J., Ilyas, M., Madronich, S. \& Tourpali, K., 2015. Ozone depletion and climate change: Impacts on UV radiation. Photochem. Photobiol. Sci. 14, 19-52.

Barnes, P.W., Flint, S.D., Rye, R.J., Tobler, M.A., Barkley, A.E. \& Wargent, J.J., 2015. Rediscovering leaf optical properties: new insights into plant acclimation to solar UV radiation. Plant Physiol. Biochem. 93, 94-100.

Berli, F.J., Moreno, D., Piccoli, P., Hespanhol-Viana, L., Silva, M.F., Bressan-Smith, R., Cavagnaro, J.B. \& Bottini, R. (2010) Abscisic acid is involved in the response of grape (Vitis vinifera $\mathrm{L}$.) $\mathrm{cv}$. Malbec leaf tissues to ultraviolet-B radiation by enhancing ultraviolet-absorbing compounds, antioxidant enzymes and membrane sterols. Plant Cell Environ. 33, 1-10.

Bertamini, M. \& Nedunchezhian, N., 2003. Photosynthetic functioning of individual grapevine leaves (Vitis vinifera L. cv. Pinot noir) during ontogeny in the field. Vitis 42, 13-17.
Caldwell, M.M., Ballaré, C.L., Bornman, J.F., Flint, S.D., Björn, L.O., Teramura, A.H., Kulandaivelu, G. \& Tevini, M., 2003. Terrestrial ecosystems, increased solar ultraviolet radiation and interactions with other climatic change factors. Photochem. Photobiol. Sci. 2, 29-38.

Canu, S., Rosati, L. Fiori, M., Motroni, A., Filigheddu, R. \& Farris, E. 2014. Bioclimate map of Sardinia (Italy). J MAPS 11, 711-718.

Cartelat, A., Cerovic, Z.G., Goulas, Y., Meyer, S., Lelarge, C., Prioul, J.L., Barbottin, A., Jeuffroy, M.-H., Gate, P., Agati, G. \& Moya. I., 2005. Optically assessed contents of leaf polyphenolics and chlorophyll as indicators of nitrogen deficiency in wheat (Triticum aestivum L.). Field Crops Res. 9, 35-49.

Castagna, A., Csepregi, K., Neugart, S. Zipoli, G., Večeřová, Jakab G., Jug, T. Llorens L.,Martínez-Abaigar, Martínez-Lüscher, Núñez-Olivera, E., Ranieri A., Schoedl-Hummel, Schreiner, M., Teszlák, P., Tittmann S., Urban, O., Verdaguer, D., Jansen, M. \& Hideg, E., 2017. Environmental plasticity of Pinot noir grapevine leaves: A trans-European study of morphological and biochemical changes along a $1,500-\mathrm{km}$ latitudinal climatic gradient. Plant Cell Environm. 40, 2790-2805.

Cerovic, Z.G., Masdoumier, G., Ben Ghozlen, N. \& Latouche, G., 2012. A new optical leaf-clip meter for simultaneous non-destructive assessment of leaf chlorophyll and epidermal flavonoids. Physiol. Plant. 146, 251-260.

Chaves, M.M, Zarrouk, O., Francisco, R., Costa, J.M., Santos, T., Regalado, A.P., Rodrigues, M.L. \& Lopes, C.M., 2010. Grapevine under deficit irrigation: hints from physiological and molecular data. Ann. Bot. 105, 661676.

Chouzouri, A. \& Schultz, H.R., 2005. Hydraulic anatomy, cavitation susceptibility and gas-exchange of several grapevine cultivars of different geographic origin. Acta Hort. 689, 325-331.

Cramer, G.R, 2010. Abiotic stress and plant responses from the whole vine to the genes. Aust. J. Grape Wine Res. 16, 86-93.

Dal Santo, S., Palliotti, A., Zenoni, S., Tornielli, G.B., Fasoli, M., Paci, P., Tombesi, S., Frioni, T., Silvestroni, O., Bellincontro, A., d'Onofrio, C., Matarese, F. Gatti, M., Poni, S. \& Pezzotti, M. 2016. Distinct transcriptome responses to water limitation in isohydric and anisohydric grapevine cultivars. BMC Genomics 17: 815 .

Del-Castillo-Alonso, M.Á., Diago, M.P., Tomás-Las-Heras, R., Monforte, L., Soriano, G., Martínez-Abaigar, J. \& Núñez-Olivera, E., 2016. Effects of ambient solar UV radiation on grapevine leaf physiology and berry phenolic composition along one entire season under Mediterranean field conditions. Plant Physiol. Biochem. 109, 374-386.

Deluc, L.G., Quilici, D.R., Decendit, A., Grimplet, J., Wheatley, M.D., Schlauch, K.A., Merillon, J.M, Cushman, J.C. \& Cramer, G.R., 2009. Water deficit alters differentially metabolic pathways affecting important flavor and quality traits in grape berries of Cabernet Sauvignon and Chardonnay. BMC Genom. 10, 212

Doupis, G., Chartzoulakis, K., Beis, A. \& Patakas, A., 2011. Allometric and biochemical responses of grapevines subjected to drought and enhanced ultraviolet-B radiation. Aust. J. Grape Wine Res. 17, 36-42.

Düring, H., 1998. Photochemical and non-photochemical responses of glasshouse-grown grape to combined light and water stress. Vitis 37, 1-4.

EEA, 2009. Water resources across Europe - Confronting water scarcity and drought. European Environment Agency, Copenhagen, Denmark.

Feller, U., 2016. Drought stress and carbon assimilation in a warming climate: Reversible and irreversible impacts. J. Plant Physiol. 203, 84-94.

Fernandes de Oliveira, A. \& Nieddu, G., 2016a. Accumulation and partitioning of anthocyanins in two red grape cultivars under natural and reduced UV solar radiation. Aust. J. Grape Wine Res. 22, 96-104. 
Fernandes de Oliveira, A. \& Nieddu, G., 2016b. Vine growth and physiological performance of two red grape cultivars under natural and reduced UV solar radiation. Aust. J. Grape Wine Res. 22, 105-113.

Fernandes de Oliveira, A., Mameli, M.G., De Pau, L., Satta, D. \& Nieddu, G., 2013. Deficit irrigation strategies in Vitis vinifera L. cv. Cannonau under Mediterranean climate. Part I - Physiological responses, growth-yield balance and berry composition. S. Afr. J. Enol. Vitic. 34, 170-183.

Fernandes de Oliveira, A., Mercenaro, L. Azzena, M. \& Nieddu, G. 2019. Effects of pre and post-veraison water deficit on Vermentino cluster microclimate and berry composition. BIO Web Conf. 13, 04015.

Fernandes de Oliveira, A., Mercenaro, L. \& Nieddu, G., 2017. Assessing thermal efficiency for berry anthocyanin accumulation in four different sites and field-growing conditions. Acta Hortic. 1188, 181-188.

Fernandes de Oliveira, A., Mercenaro, L., Del Caro, A., Pretti, L. \& Nieddu, G., 2015. Distinctive anthocyanin accumulation responses to temperature and natural UV radiation of two field-grown Vitis vinifera L. cultivars. Molecules 20, 2061-2080.

Flexas, J. \& Medrano, H., 2002. Drought-inhibition of photosynthesis in C3 plants: Stomatal and non-stomatal limitations revisited. Ann. Bot. 89, 183-189.

Flexas, J., Hendrickson, L. \& Chow, W.S., 2001. Photoinactivation of photosystem II in high light-acclimated grapevines. Aust. J. Plant Physiol. $28,755-764$.

Flick, S.E. \& Hijmans R.J. 2017. WorldClim 2: new 1-km spatial resolution climate surfaces for global land areas. Int. J. Climatol. 37, 4302-4315.

Goulas, Y., Cerovic, Z.G., Cartelat, A. \& Moya, I., 2004. Dualex: A new instrument for field measurements of epidermal ultraviolet absorbance by chlorophyll fluorescence. Appl. Opt. 43, 4488-4496.

Grifoni, D., Agati, G., Bussotti, F., Michelozzi M., Pollastrini, M. \& Zipoli, G., 2016. Different responses of Arbutus unedo and Vitis vinifera leaves to UV filtration and subsequent exposure to solar radiation. Environ. Exp. Bot. $128,1-10$.

Hugalde, I.P. \& Vila, H., 2018. Isohydric or anisohydric behaviour in grapevine ... a never-ending controversy? Rev. Investig. Agropecu. 39(1), $7 \mathrm{pp}$.

IPCC, 2018. Global warming of $1.5^{\circ} \mathrm{C}$. An IPCC Special Report on the impacts of global warming of $1.5^{\circ} \mathrm{C}$ above pre-industrial levels and related global greenhouse gas emission pathways, in the context of strengthening the global response to the threat of climate change, sustainable development, and efforts to eradicate poverty [Masson-Delmotte, V., Zhai, P., Pörtner H.O., Roberts, D., Skea, J., Shukla, P.R., Pirani, A., Moufouma-Okia, W., Péan, C., Pidcock, R., Connors, S., Matthews, J.B.R., Chen, Y., Zhou, X., Gomis, M.I., Lonnoy, E., Maycock, T., Tignor M. and Waterfield, T. (eds.)]. In Press.

Kadir, S., Von Weihe, M. \& Al-Khatib, K., 2007. Photochemical efficiency and recovery of photosystem ii in grapes after exposure to sudden and gradual heat stress. J. Amer. Soc. Hort. Sci. 132, 764-769.

Keller, M., Romero, P., Gohil H., Smithyman, R.P., Riley, W.R., Casassa, L.F \& Harbertson, J. 2016. Deficit irrigation alters grapevine growth, physiology and fruit microclimate. Am. J. Enol. Vitic. 67, 426-435.

Kolb, C.A., Käser, M.A., Kopecký, J., Zotz, G., Riederer, M. \& Pfündel, E.E., 2001. Effects of natural intensities of visible and ultraviolet radiation on epidermal ultraviolet screening and photosynthesis in grape leaves. Plant Physiol. 127, 863-875.

Liakopoulos, G., Nikolopoulos, D. \& Karabourniotis, G., 2007. The first step from light to wine: Photosynthetic performance and photoprotection of grapevine (Vitis vinifera L.) leaves. Funct. Plant Sci. Biotechnol. 1, 112-119.

Lopes, C.M. \& Pinto, P.A., 2005. Easy and accurate estimation of grapevine leaf area with simple mathematical models. Vitis 44, 55-61.
Lovisolo, C., Lavoie-Lamoureux, A., Tramontini S. \& Ferrandino, A., 2016. Grapevine adaptations to water stress: New perspectives about soil/plant interactions. Theor. Exp. Plant Physiol. 28, 53-66.

Lovisolo, C., Perrone, I. Carra A., Ferrandino A., Flexas, J., Medrano H. \& Schubert, A., 2010. Drought-induced changes in development and function of grapevine (Vitis spp.) organs and in their hydraulic and non-hydraulic interactions at the whole-plant level: A physiological and molecular update. Funct. Plant Biol. 37, 98-116.

Luo, H.-B., Ma, L., Xi, H.-F., Duan, W., Li, S.-H., Loescher, W., Wang, J.-F. \& Wang, L.-J., 2011. Photosynthetic responses to heat treatments at different temperatures and following recovery in grapevine (Vitis amurensis L.) leaves. PLoS ONE 6: e23033.

Martínez-Lüscher, J., Morales, F., Delrot, S., Sánchez-Díaz, M., Goméa, E., Aguirreolea, J. \& Pascual, I., 2013. Short- and long-term physiological responses of grapevine leaves to UV-B radiation. Plant Sci. 213, 114-122.

Morales, L.O., Brosché, M., Vainonen, J., Jenkins, G.I., Wargent, J.J., Sipari, N., Strid, Å., Lindfors, A.V., Tegelberg, R. \& Aphalo, P.J., 2013. Multiple roles for UV RESISTANCE LOCUS8 in regulating gene expression and metabolite accumulation in Arabidopsis under solar ultraviolet radiation. Plant Physiol. 161, 744-759.

Myburgh, P.A., 2011. Responses of Vitis vinifera L. cv. Merlot to low frequency deficit irrigation and partial root zone drying in western Cape Coast region - Part I. Soil and plant water status. S. Afr. J. Enol. Vitic. 32, 89-103.

Palliotti, A. \& Poni, S., 2016. Grapevine under light and heat stresses. In: Gerós, H., Chaves, M.M., Medrano, H.G. \& Delrot, S. (eds). Grapevine in a changing environment: A molecular and ecophysiological perspective. John Wiley \& Sons, Ltd, Chichester, UK. pp. 148 - 178.

Poni, S., Gatti, M., Palliotti, A., Dai, Z., Duchêne, E., Truong, T-T., Ferrara, G., Matarrese, A.M.S., Gallotta, A., Bellincontro, A., Mencarelli, F. \& Tombesi, S., 2018. Grapevine quality: A multiple choice issue. Sci. Hortic. $234,445-462$.

Potters, G., Jansen, M.A.K., Guisez, Y. \& Pasternak, T., 2006. Stress drives plant cells to take the road towards embryogenesis. In: Teixeira da Silva, J.A. (ed). Floriculture, ornamental and plant biotechnology, advances and topical issues, vol. 2. Global Science Books Ltd., London. pp. $289-294$.

Rogiers, S.Y., Greer, D.H., Hutton, R.J. \& Landsberg, J.J., 2009. Does night-time transpiration contribute to anisohydric behaviour in a Vitis vinifera cultivar? J. Exp. Bot. 60, 3751-3763.

Sade, N., Gebremedhin, A. \& Moshelion, M., 2012. Risk-taking plants. Plant Signal Behav, 7, 767-770.

Sanchez-Lorenzo, A., Enriquez-Alonso, A., Calbó, J., González, J.-A., Wild, M., Folini, D., Norris, J.R. \& Vicente-Serrano, S.M., 2017. Fewer clouds in the Mediterranean: Consistency of observations and climate simulations. Sci. Rep. 7, Art. No. 41475.

Schultz, H.R., 2003. Differences in hydraulic architecture account for nearisohydric and anisohydric behaviour of two field-grown Vitis vinifera L. cultivars during drought. Plant, Cell Environ. 26, 1393-1405

Šebela, D., Turóczy, Z., Olejníčková, J., Kumšta, M. \& Sotolář R., 2017. Effect of ambient sunlight intensity on the temporal phenolic profiles of Vitis vinifera L. cv. Chardonnay during the ripening season - A field study. S. Afr. J. Enol. Vitic. 38(1), 94-102.

Smart, R.E. \& Robinson, M., 1991. Sunlight into wine. A handbook for winegrape canopy management. Winetitles, Adelaide, SA, Australia.

Soar, C.J., Speirs, J., Maffei, S.M., Penrose, A.B., McCarthy, M.G. \& Loveys, B.R., 2006. Grapevine varieties Shiraz and Grenache differ in their stomatal response to VPD: Apparent links with ABA physiology and gene expression in leaf tissue. Aust. J. Grape Wine Res. 12, 2-12. 
Strasser, R.J., Tsimilli-Michael, M. \& Srivastava, A., 2004. Analysis of the fluorescence transient. In: Papageorgiou G.C. \& Govindjee (eds). Advances in photosynthesis and respiration series. Chlorophyll fluorescence: A signature of photosynthesis. Springer, Dordrecht, The Netherlands. p. 321 -362 .

Teramura, A.H. \& Sullivan J.H. 1991. Potential impacts of increased solar UV-B on global plant productivity. Photobiology, 625-634.

Wahid, A., Gelani, S., Ashraf, M. \& Foolad, M.R., 2007. Heat tolerance in plants: An overview. Environ. Exp. Bot. 61, 199-223.

Wild, M., Folini, D., Henschel, F., Fischer, N. \& Müller, B., 2015. Projections of long-term changes in solar radiation based on CMIP5 climate models and their influence on energy yields of photovoltaic systems. Sol. Energy 116, 12-24.
Xu, H., Liu, G., Liu, G., Yan, B., Duan, W., Wang, L. \& Li, S., 2014. Comparison of investigation methods of heat injury in grapevine (Vitis) and assessment to heat tolerance in different cultivars and species. BMC Plant Biol., 14:156.

Young, P.R., Eyeghe-Bickong, H. A., Du Plessis, K., Alexandersson, E., Jacobson, D.A., Coetzee, Z., Deloire, A. \& Vivier, M.A., 2016. Grapevine plasticity in response to an altered microclimate: Sauvignon blanc modulates specific metabolites in response to increased berry exposure. Plant Physiol. $170,1235-1254$

Zarrouk, O., Costa, J.M., Francisco, R., Lopes C. \& Chaves, M.M., 2016. Drought and water management in Mediterranean vineyards. In: Gerós, H., Chaves, M.M., Medrano, H.G. \& Delrot, S. (eds). Grapevine in a changing environment: A molecular and ecophysiological perspective. John Wiley \& Sons, Ltd, Chichester, UK. pp. $38-67$.

Zlatev, S.Z., Lidon F.J.C. \& Kaimakanova, M., 2012. Plant physiological responses to UV-B radiation. Emir. J. Food Agric. 24, 481-501. 